\title{
Sığınmacıların Toplumsal Uyum Sorunları ve Sosyal Hizmetlere Erişimi: Düzce Uydu Kent Örneği
}

\author{
Emel Coşkun ${ }^{1}$ (1) \\ Çetin Yılmaz ${ }^{2}$
}

Öz

Bu yazı Düzce uydu kentinde yaşayan Irak, İran, Suriye ve Afganistanlı sığınmacıların toplumsal yaşama uyumda ve sosyal hizmetlere erişimde yaşadıkları sorunları ele almaktadır. Nitel araştırma yaklaşımının benimsendiği bu çalışma kapsamında, 21 sığınmacı ve sığınmacıların bu hizmetlere erişiminde kilit konumdaki iki kamu çalışanı ile derinlemesine görüşmeler yapılmıştır. Ayrıca eğitim, sağlık ve sosyal hizmet alanında çeşitli kamu kuruluşlarının ve sivil toplum kuruluşlarının sığınmacılara yönelik faaliyetleri incelenmiştir. Çalışma bulguları Türkiye'de de sığınmacılara eğitim, sağlık ve sosyal yardımlara erişim gibi bir takım sosyal haklar tanınmakta birlikte sığınmacıların bu haklara erişiminde sorunlar yaşadığını göstermektedir. Türkçe dil engeli, çalışma zorunluluğu, sağlık sorunları ve toplumsal cinsiyete dayalı sorumluluklar gibi engeller bu haklara erişimi kısıtlayabilmektedir. Düzce'deki sığınmacılar sağlıklı barınma olanaklarına erişememekte, düşük ücretli çalışma veya ücretini alamama sorunları ile karşılaşmakta, toplumsal dışlanma ve damgalanma gibi farklı sorunlarla baş başa kalmakta ve karşılaştikları sorunlar savaşın yol açtığı psikolojik sorunlarını daha da derinleştirmektedir. Özellikle tek ya da çocuklarıyla yaşayan sığınmacı kadınların psiko-sosyal ve ekonomik destek mekanizmalarına kısıtlı erişimi, iş ve yardım arayışlarında onları cinsel taciz gibi toplumsal cinsiyete dayalı risklere maruz bırakmaktadır. Sığınmacıların ihtiyaçlarına yerel düzeyde sivil toplumun desteği ile ve sosyal çalışmacılarının dahil olmadığı bir "hayırseverlik" anlayışı ile çözüm üretilmesine çalışımaktadır. Sığınmacılar çocuk, genç, yaşlı, engelli ve tek yaşayan kadınlar gibi farklı gruplardan oluşmaktadır ve bu grupların farklı sorunları ve ihtiyaçları bulunmaktadır. Düzce'deki sığınmacıların erişebileceği insan hakları merkezli toplumsal cinsiyete duyarlı psiko-sosyal destek mekanizmalarının kurulması gerekmektedir.

\section{Anahtar Kelimeler}

Sığınmacılar • Mülteciler • Uydu kent • Toplumsal cinsiyet • Mültecilerle sosyal hizmet

\footnotetext{
* Bu araştırma Düzce Üniversitesi Bilimsel Araştırma Projeleri Müdürlüğü tarafindan desteklenmiştir (Proje No: 2018.05.06.822).

1 Sorumlu Yazar: Emel Coşkun (Dr. Öğr. Üyesi), Düzce Üniversitesi, Fen-Edebiyat Fakültesi, Sosyoloji Bölümü, Sakarya, Türkiye. Eposta: emelcoskun@duzce.edu.tr

2 Çetin Yılmaz (Dr. Öğr. Üyesi), Düzce Üniversitesi, Sağlık Bilimleri Fakültesi, Sosyal Hizmet Bölümü, Sakarya, Türkiye. Eposta: cetin.yilmaz@duzce.edu.tr
}

Atıf: Coşkun, E. ve Yılmaz, Ç. (2018). Sığınmacıların toplumsal uyum sorunları ve sosyal hizmetlere erişimi: Düzce uydu kent örneği. Sosyal Siyaset Konferansları Dergisi, 75, 269-305. http://dx.doi.org/10.26650/jspc.2018.75.0016 


\title{
Asylum Seekers' Social Integration Problems and Access to Social Services: A Case of Düzce Satellite City
}

Emel Coşkun ${ }^{1}$

\author{
Çetin Yılmaz
}

\begin{abstract}
This paper analyzes the problems that Iraqi, Iranian, Syrian, and Afghan asylum seekers face in social integration and in accessing social services in the satellite city of Düzce. Adopting a qualitative research approach, in-depth interviews with 21 asylum seekers and two key informants from public institutions were conducted. Additionally, several public institutions in education, health, and social services, as well as non-governmental organizations' activities for asylum seekers, were investigated. Our findings show that although asylum seekers are entitled to some social rights, including education, health services, and employment, they have difficulties accessing these rights due to language barriers, work obligations, health problems, and gendered responsibilities. Asylum seekers cannot access healthy accommodations and usually hold low-paying or irregular employment with uncertain pay, and face social exclusion and stigmatization in Düzce. These problems deepen their psychological problems caused by the war. Asylum seekers consist of different groups including children, youth, the elderly, disabled individuals, and single women, all with different problems and needs. In particular, female asylum seekers living alone or with children are exposed to gender-based risks, including sexual harassment, in their search for employment or aid, and they have limited access to psycho-social and economic support. At local level, the needs of asylum seekers are met through a "philanthropist" approach where social workers are not involved. There is a need to build human rights-centered, gender-sensitive, accessible psycho-social, and economic support mechanisms for asylum seekers in Düzce.
\end{abstract}

\section{Keywords}

Asylum seekers • Refugees • Satellite city • Gender and social work with refugees

1 Corresponding author: Emel Coşkun (Lecturer), Duzce University, Faculty of Letters, Department of Sociology, Sakarya, Turkey. Email:emelcoskun@duzce.edu.tr

2 Çetin Yılmaz (Lecturer), Faculty of Health Sciences, Social Service Department, Sakarya, Turkey.

Email: cetin.yilmaz@duzce.edu.tr

To cite this article: Coşkun, E. \& Yılmaz, Ç. (2018). Asylum seekers' social integration problems and access to social services: A case of Düzce Satellite city. Journal of Social Policy Conferences, 75, 269-305, http://dx.doi.org/10.26650/jspc.2018.75.0016 


\section{Extended Summary}

Turkey has been caught unprepared for the influx of asylum seekers and migrants since the 1990s and the increasing number of refugees fleeing the Syrian war since 2011. Today, more than 3.5 million Syrians and over 300,000 non-Syrian asylum seekers are residing in Turkey. They are among the most disadvantaged groups in Turkish society. Turkey's migration and asylum system has been undergoing a transition process since the early 2000s. Recently, the Law on Foreigners and International Protection (LFIP) in 2013 and the Regulation on Temporary Protection (RTP) in 2016 have been adopted to categorize and manage different asylum-seeker groups. The main difference between them is that non-Syrian asylum seekers can apply for international protection to be resettled to a third country and must register in a satellite city. Today, there are more than 60 satellite cities as defined by the Ministry of Interior Directorate General of Migration Management (DGMM). According to the Article 82-1 of Law on Foreigners and International Protection (2014), refugees and asylum seekers are only allowed to live in satellite cities for reasons of security and public order, and to prevent accumulation in big cities. Düzce is one of the satellite cities as defined by DGMM. More than seven thousand asylum seekers, mostly from Iraq, Syria, Iran and Afghanistan, are currently living in Düzce. This paper explores the difficulties of accessing social services and the social integration problems of asylum seekers in Düzce from a gender- and human rights-based social-work perspective.

This paper is based on an empirical research using a qualitative approach and a snowball sampling method. In-depth interviews with 21 asylum seekers and two key informants from public institutions, Düzce Governorship and the City Branch of Migration Management, were conducted. In addition, several public institutions in education, health, and social services, as well as non-governmental organizations' activities for asylum seekers, were investigated. The socio-economic support options in Düzce include free education for children, Turkish-language courses for adults, free access to health care (including free medications) and 120 TRY given by Kizllay Card to meet some requirements such as food and shelter. Also, some NGOs provide irregular economic support based on humanitarian aid. Our findings show that although asylum seekers are entitled to access some social services, including education, health services or employment, they have difficulties accessing them due to language barriers, work obligations, health problems, and gendered responsibilities.

Asylum seekers cannot access healthy accommodations and usually face lowpaying or irregular employment and/or non-payment problems, social exclusion and stigmatization in Düzce; and these problems deepen their psychological problems

3 This research was supported by Duzce University Scientific Research Projects Coordination Unit(Project No: 2018.05.06.822). 
caused by the war. In particular, female asylum seekers have serious problems meeting their daily needs, such as food and shelter, accessing to health care, and public services. As a result of limited access to psycho-social and economic support mechanisms, female asylum seekers face unique gender-based risks, including sexual harassment in their search for employment or aid.

At the local level, the needs of asylum seekers are met through a "philanthropist" approach, where social workers are not involved. Asylum seekers consist of different groups, including children, youth, the elderly, disabled individuals, and single women, and they all have different problems and needs. Based on empirical research, some recommendations can be made to support asylum seekers more effectively. In general, these recommendations include the empowerment of asylum seekers via different support mechanisms, such as an easy access to multi-lingual information services, accommodation, and human rights-based socio-economic supports. Most importantly, in order to fight against gender-based violence, human rights based and gender-sensitive psycho-social and economic support mechanisms should be developed for female asylum seekers in Düzce and all over Turkey. 


\section{Sığınmacıların Toplumsal Uyum Sorunları ve Sosyal Hizmetlere Erişimi: Düzce Uydu Kent Örneği}

Türkiye 1990'lardan itibaren artan sığınmacı ve göçmen akımları ile 2011'de Suriye savaşının başlamasıyla sayıları hızla artan mülteciler karşısında hazırlıksız yakalanmıştır. Birleşmiş Milletler Mülteciler Yüksek Komiserliği'nin (BMMYK) 2017 yılı Aralık verilerine göre, bugün Türkiye'de ikamet eden uluslararası korumaya başvuran çeşitli milletlerden sığınmacıların sayısı 300 binden fazladır, Suriyeli sığınmacıların sayısı ise 3,5 milyonu aşmıştır. Daha geniş anlamda politik, ekonomik ve toplumsal etkileri bir yana, toplumdaki konumları açısından sığınmacılar ve mülteciler sosyal hizmetlere ihtiyaç duyan gruplar arasında en dezavantajlı gruplardan birisidir. Ülkelerinde savaşın travmasını yaşayan, ailesi bölünen ya da akrabalarını kaybeden sığınmacı ve mültecilerin sı̆̆ındıkları ülkelerde de barınma, beslenme, giyim, psiko-sosyal yardımlara erişim, yabancı dil engeli ve kendini ifade edememe, kimliksizlik, farklı bir kültüre alışma, depresyon ve stres bozukluğu gibi sorunlar yaşadıkları bilinmektedir (Buz, 2008).

Halen göç ve sığınma rejimi bir değişim sürecinden geçen Türkiye'de 2013 yılında çıkarılan Yabancılar ve Uluslararası Koruma Kanunu (YUKK) ve 2016 yılında çıkarılan Geçici Koruma Yönetmeliği mevcut sığınma rejiminin çerçevesini oluşturmaktadır. Temelde Suriyeli ve Suriyeli olmayanlar olarak tanımlanan iki farklı sığınmacı grup arasındaki asıl ayrım Suriyeli olmayan sığınmacıların BMMYK aracılığıyla uluslararası korumaya başvurma ve üçüncü bir ülkeye yerleştirilme hakkının olmasıdır. Türkiye, Birleşmiş Milletler Mültecilerin Statüsüne İlişkin Sözleşme’yi (Cenevre Sözleşmesi, 1951) coğrafi çekince ile imzalayarak Avrupa Birliği dışından gelen sığınmacılara mülteci statüsü vermemektedir. Uluslararası mülteci rejimi, 'mülteci' olarak tanımlanan kişilere devletlerin kendi vatandaşlarına sağlanan çoğu hakkın sağlanmasını öngörmektedir (BMMYK, 1951). Bu haklar arasında korunma, insan onuruna yakışır muamele, eğitime erişim, işyeri açmak, istihdama erişim, mülk edinmek, evlenmek, ülke içinde serbest dolaşım hakkı ve adli yardıma başvuru gibi önemli haklar bulunmaktadır (A.g.e.). Türkiye'de Uluslararası Koruma Rejimi altında kalan Suriyeli olmayan sığınmacıların Türkiye'de BMMYK ve Göç İdaresi Genel Müdürlüğü (GİGM) tarafından “mülteci” olarak tanımlanarak üçüncü ülkeye yerleştirilene kadar uydu kentlerde yaşamak zorunluluğu vardır. Eğitim, sağlık gibi bir takım sosyal haklara erişim için uluslararası koruma altındaki sığınmacıların uydu kentlerde ve İl Göç İdaresi 
Müdürlükleri'ne kayıt yaptırarak yaşamak zorundadırlar. Uluslararası korumaya başvurma hakları olmayan Suriyeliler için ise bu süreç Geçici Koruma Rejimi olarak tanımlanmakta ve eğitim, sağlık, istihdama erişim gibi alanlarda nispeten daha geniş haklar tanımlanmaktadır. GİGM tarafından sı̆̆ınmacıların ikameti için belirlenen uydu kent sayısı bugün 60'tan fazladır. YUKK (2013) Madde 82-1'e göre mülteciler güvenlik, toplum düzenini sağlamak ve büyük şehirlerde yığılmayı önlemek için sadece uydu şehirlerde ikamet edebilmektedir.

Özellikle savaştan kaçan Suriyelilerin sınırlan geçmeye başlaması ile sığınmacı ve mülteciler üzerine Türkiye'de yapılan araştırmaların sayısı hızla artmaktadır. Bu alandaki araştırmalar Afet ve Acil Durum Yönetimi Başkanlığg (AFAD) gibi kamu kurumları tarafindan yapılan durum tespit raporları (AFAD, 2014) ya da sivil toplum örgütleri tarafindan yapılan durum tespiti, ihtiyaç analizi ve raporlama (Erdoğan, 2015; Biner ve Soykan, 2016; Kaya ve Kıraç, 2016) faaliyetlerinde yoğunlaşmaktadır. Sayıları hızla artan akademik araştırmalar içerisinde sığınmacı ve mülteciler ile ilgili güvenlik, sağlık, istihdam, psikolojik sorunlara ve sosyal politikaya odaklı akademik araştırmaların sayısı hızla artmaktadır (Jessen, 2013; İçduygu, 2015; Erdoğan, 2015; Güney ve Konak, 2016). Sığınmacıların uydu kentlerdeki yaşamına dair sosyal hizmet perspektifinden bakan araştırma sayısı kısıtlıdır (Coşkun, 2017; Erder, 2017; Tekin ve Ertuş, 2017).

GİGM tarafından uluslararası koruma başvurusunda bulunan Suriye dışından sığınmacıların ve geçici koruma altında Suriyelilerin gönderildiği illerden birisi de Düzce'dir. Düzce Göç İdaresi İl Müdürlüğü ve Düzce Valiliği tarafindan kentte büyük kısmı Irak, İran, Suriye ve Afganistan'dan olmak üzere yaklaşık yedi bin sığınmacı ikamet ettiği söylenmektedir. Ayrıca bin 500'den fazla ikamet izni alan göçmen olduğu ve yüzlerce kağıtsı göçmen ya da sığınmacının da yaşadığı bilinmektedir. Savaşın travmasından kaçan sığınmacıların gündelik yaşamlarında da barınma, ekonomik zorluklar, eğitim ve sağlık alanında hizmetlere erişimde zorluklarla karşılaştıkları bilinmektedir. Bu araştırma da Düzce'deki sığınmacıların toplumsal yaşama uyum sürecinde karşılaştıkları zorluklara ve erişilebilir sosyal hizmetler çerçevesinde uyum stratejilerine odaklanmaktadır.

\section{Türkiye'de Sığınmacılara Yönelik Sosyal Hizmetler}

Türkiye' de 1983 yılında yürürlüğe giren 2828 Sayılı Sosyal Hizmetler Kanununa göre sosyal hizmetler "kişi ve ailelerin kendi bünye ve çevre şartların- 
dan doğan veya kontrolleri dışında oluşan maddi, manevi ve sosyal yoksunluklarının giderilmesine ve ihtiyaçlarının karşılanmasına, sosyal sorunlarının önlenmesi ve çözümlenmesine yardımcı olunmasını ve hayat standartlarının iyileştirilmesi ve yükseltilmesini amaçlayan sistemli ve programlı hizmetler bütününü’ olarak tanımlanmaktadır (Sosyal Hizmetler Kanunu, 2017).

Mülteci ya da sığınmacı olarak yaşamak başlı başına birçok psiko-sosyal sorunu beraberinde getirmektedir. Birçok mülteci ülkesini terk etmeden önce işkence, baskı ve tecavüz gibi farklı zulüm biçimlerine maruz kalmaktadır. Göç sırasında gidilen tehlikeli yol, süre, zorlu yaşam koşulları, şiddet, kamp hayatı, aile ve akrabalık bağlarının çözülmesi gibi travmatik olaylar mültecileri etkilemektedir. Göç sonrasında ise; mültecilik statüsündeki belirsizlik, işsizlik, barınma, sağlık, eğitim gibi en temel insani hizmetlere erişmede yaşanan zorluklar, dil öğrenme, sosyal ve kültürel uyum sorunları, sosyal destek ağlarının parçalanması, geleceğe dair belirsizlikler en sık rastlanan sorunlardır (Demirbaş ve Bekaroğlu, 2013). Türkiye'de de sığınmacılar bekleme sürelerinin uzamasıyla birlikte gündelik hayatlarını kendi başlarına sürdürme noktasında birçok sorunla karşılaşmaktadırlar.

Türkiye'de sığınmacılara yönelik sosyal hizmetlerin kapsamlı, sistemli ve programlı hizmetler bütünü olduğunu söylemek oldukça güçtür. Bunun en önemli sebebinin Türkiye'nin bir 'geçiş ülkesi' olarak görülmesinden kaynaklandığı söylenebilir (Buz, 2008). Nitekim BMMYK aracılığıyla uluslararası korumaya başvuran $\mathrm{AB}$ vatandaşı olmayan kişiler, üçüncü bir ülkeye yerleştirilene kadar Türkiye'de beklemek ve yaşamak zorunda kalmaktadır. Özellikle Suriye savaşından sonra Suriyeli olmayanlar için bu bekleme süresi daha da uzamıştır. BM'nin Göç Ajansı olan Uluslararası Göç Örgütü (UGÖ) verilerine göre 2016 yılında Türkiye'den üçüncü ülkelere yerleştirilen çoğu kadın ve çocuk 21 bin mültecinin yarısından çoğu (yüzde 62) Suriyelidir; Suriyeli mültecileri sırasıyla Iraklı (yüzde 24) ve İranlılar (yüzde 9) takip etmektedir (UGÖ, 2017). Türkiye'den uluslararası korumaya başvurma hakları olmamakla birlikte aile birleşmesi ya da 'acil' olarak tanımlanan durumlar için Suriyeliler başta Avrupa olmak üzere üçüncü ülkelere yerleştirildiklerini burada not düşmek gerekmektedir. Tüm bu veriler bize Türkiye'de ikamet eden sığınmacıların uzun yıllar burada yaşamak zorunda kaldıklarını göstermektedir. 
Türkiye' de bulunan sığınmacıların eğitim, sağlık, sosyal yardımlara erişme ve çalışma hakları -kimi kısıtlamalarla birlikte- YUKK' da (2013) düzenlenmiştir. Sığınmacıların zorunlu olan ilköğretim ve ortaöğretime erişim faydalanma hakları vardır. Ancak bu bir zorunluluk olarak görülmemekte aile isterse kullanılabilecek bir hak olarak görülmektedir. Bunun yanı sıra, her hangi bir sosyal güvencesi olmayan ve ödeme gücü bulunmayan sığınmac1lar 5510 sayılı Sosyal Sigortalar ve Genel Sağlık Sigortası hükümlerine tabi kılınarak sağlık hakları güvenceye alınmıştır. Ayrıca ihtiyacı olan sığınmacılardan sosyal hizmet ve yardımlara erişim hakları bulunmaktadır. Sığınmacılar için ulusal çapta maddi yardımlar Avrupa Birliği tarafından finanse edilen 'Yabancılara Yönelik Sosyal Uyum Yardımı Programı' (SUY) çerçevesinde düzenlenmektedir. Kasım 2016'da başlayan ve bütçesi ilk etapta 348 milyon Avro olan SUY'un amacı, Türkiye'deki uluslararası koruma ve geçici koruma kapsamında, kamp dışında yaşayan yardıma ihtiyacı olan sığınmacılara nakit yardım ile uyum sorunlarının çözümüne destek olmaktadır. Bu yardımlarla Türkiye'de yaşayan bir milyondan fazla ihtiyaç sahibinin yiyecek, yakacak, kira ve faturalarını karşılamalarına katkı sağlanması hedeflenmiştir. SUY programına başvurular, Aile Sosyal Politikalar Bakanlığı'na (ASPB) bağlı Sosyal Yardımlaşma ve Dayanışma Vakfı (SYDV) İl Müdürlükleri’ne ve Türk Kızılayı'na yapılmaktadır. Başvuruları uygun bulunan kişilere Kızılay Kart verilmektedir. Kızılay Kart, SUY çerçevesinde AB tarafında finanse edilmekte ve Türk Kızılayı, Aile Sosyal Politikalar Bakanlığı ve Dünya Gıda Programı (WFP) işbirliğiyle uygulanmaktadır. SUY'un genel koordinasyonu AFAD sağlamaktadır. SYDV'ye başvurular aracılığıyla ihtiyacı olan mültecilere dağıtılan Kızılay Kart'a her ay fert başına 120 lira yüklenmektedir. Bu kart ile ATM'lerden para çekilebilmekte ya da kredi kartı olarak alışveriş yapılabilmektedir. Uluslararası Koruma ve Geçici Koruma rejimi altındaki sığınmacıların Kızılay Kart'a erişebilmeleri için bir takım kıstasları karşılamaları gerekmektedir. Yardımlarda tek ya da çocuklu yaşayan tek kadınlar, engelliler, dört ve daha fazla çocuklu aileler ile dezavantajlı gruplara öncelik verilmektedir. 2018 yılı sonuna kadar sürmesi beklenen bu programa SYDV ve 168 numaralı Kızılay Çağrı Merkezi’nden de başvurulabilmektedir.

Türkiye'de sığınmacılar için en önemli ihtiyaçlardan birisi barınmadır. Sığınmacıların barınma ihtiyacını kendilerinin karşılaması beklenmektedir. Sığınmacılar atandıkları uydu kentlerde kendi imkânlarıyla ikamet etmek zorundadırlar 
ve kendilerinden istenilen sürelerde bildirimde (imza) bulunmak zorundadirlar. Uluslararası koruma başvurusunda bulunan sığınmacılar için GİGM tarafindan işletilen biri Yozgat, diğer Tekirdağ' da olmak üzere toplam 150 kişi kapasiteli iki barınma ve kabul merkezi bulunmaktadır. Dolayısıyla bazı kentlerde sığınmacılar için barınma imkânları yerel yönetimlerin inisiyatifleriyle geliştirilmiş olmakla birlikte çoğu uydu kentte bu imkânlar bulunmamaktadır. Sadece Suriyeliler için sınır kentlerde sayıları yirmiyi geçen kamplar bulunduğunu not düşmek gerekmektedir. Sınırlı ekonomik imkânlara sahip sığınmacılar için barınma çoğu zaman büyük bir probleme dönüşmektedir.

İstihdamla ilgili düzenlemelere baktığımızda ise Türkiye'de sığınmacıların çalışma hakkının 2003 yılında çıkarılan 4817 Sayılı 'Yabancıların Çalışma İzinleri Hakkında Kanun' temel alınarak düzenlendiği görülmektedir. 2014 yılında yürürlüğe giren YUKK ve 2016'da kabul edilen 'Geçici Koruma Sağlanan Yabancıların Çalışma İzinlerine Dair Yönetmelik' ve “Uluslararası İşgücü Kanunu' (No: 6735) ile Suriyeli ve Suriyeli olmayanlar için çalışma izinlerine başvuru kolaylaştırılmıştır (ÇSGB, 2016). Türkiye'de hem geçici koruma hem de uluslararası koruma kapsamındaki sı̆̆ınmacıların çalışma iznine başvurusu ancak koruma başvuru tarihinden itibaren altı ay ikamet sonrasında ve ancak işveren tarafından yapılabilmektedir. İşverenlerin 'yabancı' çalıştırmak için 492 Sayılı Harçlar Kanunu hükümlerince 'çalışma izni harcı' ödemek zorunda olması, işverenleri yabancı işçi çalıştırma konusunda isteksiz davranmaya itmektedir. 2018 yılı için harçlar Uluslararası Koruma altındaki kişiler için 615,20 TL, Geçici Koruma altındaki Suriyeliler için 228,90 TL olarak hesaplanmıştır (ÇSGB, 2018).

Çalışma ve Sosyal Güvenlik Bakanlığı (ÇSGB) rakamlarına göre, Türkiye' de 2015 yılı itibariyle 64 bin 547 yabancıya çalışma izni verilmiştir. Fakat bu rakamın gerçek durumu yansıtmaktan oldukça uzak olduğu görülmektedir. Çünkü Türkiye'de sadece 600 bin Suriyelinin kayıt dışı istihdam edildiği tahmin edilmektedir (Kaygısız, 2017). Her ne kadar YUKK düzenlemeleri ve 11 Ocak 2016 tarihinde yürürlüğe giren 'Geçici Koruma Sağlanan Yabancıların Çalışma İzinlerine Dair Yönetmelik’ Suriyelilerin çalışma izni başvuru sürecini kolaylaştırmış olsa da hem sektörel hem de iş yeri bazlı k1sitlamalar doğrultusunda sığınmacıların çalışma iznine erişimleri hala zordur (Coşkun, 2017). Nitekim yönetmeliğin 8 (2). maddesi, çalışma iznine başvu- 
rulan iş yerinde 'yabancı' işçi sayısının o iş yerinde çalışan vatandaş sayısının yüzde onunu geçemeyeceğini vurgulamaktadır, bu oran Suriyeliler için "toplam çalışan sayısı ondan az olan işyerlerinde, geçici koruma sağlanan en fazla bir yabancıya çalışma izni verilebilir” şeklinde düzenlenmiştir (Resmi Gazete, 2016). ÇSGB (2016) verileri 2015 yılında 280'i kadın, 3.739'u erkek olmak üzere toplamda 4.019 Suriyeli mültecinin çalışma izni aldığını göstermektedir. Rakamın bu derece az olması sığınmacıların emek piyasasına enformel bir şekilde eklemlendiklerini kanıtlar niteliktedir.

Mevcut yasal düzenlemeler ve kısıtlı sosyal hizmetler Türkiye'deki sığınmacıların içinde bulundukları yaşam koşulları hakkında bize bilgi vermektedir. Barınma ve maddi ihtiyaçlarını temelde kendilerinin karşılaması beklenen s1ğınmacıların başta psiko-sosyal destek hizmetleri olmak üzere sosyal hizmetlere erişmede sorunlar yaşadıkları bilinmektedir (Buz, 2005; 2008). Nitekim Türkiye'de sosyal hizmetlere erişim bir 'sosyal hak' olarak görülmesinden öte 'hayırseverlik' temelinde yapılandırılmakta bu da sığınmacılara yönelik düzenli psiko-sosyal destek mekanizmalarının kurulmasını engellemektedir. Hak temelli yaklaşım, sosyal hizmetleri 'hayır' için değil, kişilerin ve toplumsal grupların 'hakkı' olduğu için gerçekleştirir. Hak temelli yaklaşım, görev sahiplerini sorumluluklarını yerine getirmeleri, hak sahiplerini de haklarını talep etmelerini konusunda güçlendirir (Tufan, vd., 2009). Bir hak, sahibine, onu isteme, sahip olduğunda onu koruma ve ondan yararlanma gücü vermektedir. Dolayısıyla hak kavramı ve yetki arasında yakın bir bağlılık vardır. Hak sahibi bu yetkiyi kullandığı zaman karşı taraf için bir yükümlülük, bir ödev ortaya çıkmaktadır (Emini'den akt. Zengin ve Altındağ, 2016, s.180). Türkiye'de de tüm dünyada 1980'li yıllarla birlikte meydana gelen neo-liberal dönüşüme paralel olarak devletlerin sosyal sorunları çözmek için yerine getirmesi gereken sorumluluklar, 'refah karması' (welfare mix) anlayışı çerçevesinde piyasaya, sivil topluma ve dini kurumlara havale edilmektedir (Taşğın ve Özel, 2011).

Bu çalışma da mevcut yasal düzenlemeler ışığında Düzce'deki sığınmac1ların yararlanabileceği erişilebilir sosyal hizmet mekanizmalarını yerel uygulamalar çerçevesinde sığınmacıların perspektifinden ampirik bir araştırmaya dayanarak incelemektedir. 


\section{Yöntem}

Düzce'deki uluslararası koruma ve geçici koruma altındaki sığınmacıları ele alan bu çalışmada nitel araştırma yaklaşımı benimsenmiştir. Araştırmada veri toplama aracı olarak yarı-yapılandırılmış derinlemesine görüşmeler kullanılmıştır. Bu yöntem özellikle sığınmacılar gibi dezavantajlı grupların deneyimlerini kendi perspektiflerinden aktarmak için tercih edilen bir yöntemdir.

Araştırma kapsamında Düzce'de ikamet eden uluslararası koruma ve geçici koruma altındaki Irak, İran ve Suriyeli yedi kadın ve on dört erkek sığınmacı ile derinlemesine görüşmeler yapılmıştır. Valilik bünyesindeki Kardeşlik Akrabalık ve Dostluk İletişim Merkezi (KADİM) ve İl Göç İdaresi gibi sosyal hizmetlere yönlendirme yapılan kilit kamu kurumlarındaki iki çalışan ile de görüşülmüsstür. Ayrıca sığınmacılara psiko-sosyal ya da ekonomik olarak destek sağlayan ya da bu destekleri vermekte yetkili olan kamu kurum ve kuruluşları ile sivil toplum örgütlerinin faaliyetleri de araştırma kapsamında incelenmiştir. Bu incelemelerde Düzce Üniversitesi Sosyal Hizmet Bölümü 3. Sınıf öğrencilerinin kentteki kamu kurumlarıyla yaptıkları görüşmelerden yararlanılmıştır. Bu kurumlardan bazıları eğitim alanında İl Milli Eğitim Müdürlüğü, Halk Eğitim Merkezi Müdürlüğü ve Gençlik Merkezi Spor İl Müdürlügü̈, AFAD, Kızılay, İŞKUR, Düzce Barosu ve İnsan Hak ve Hürriyetleri (İHH) Derneği gibi sivil toplum kuruluşlarıdır. Çalışma kapsamında ayrıca İHH Düzce'den bir yetkili derse davet edilerek kentteki deneyimlerini paylaşması için sorular yöneltilmiştir

Özellikle sığınmacılarla araştırmalar, toplumdaki dezavantajlı kişileri kapsadığından etik sorunları içeren bir alandır. Bundan dolayı, elde edilen bilgi kadar bilgiye nasıl erişildiği, bilginin nasıl anonimleştirileceği ve hangi amaçla kullanılacağı önemli etik konuları kapsamaktadır. Bu sorunların bilincinde olarak görüşülenlere kayıt yaptırdıkları kamu kurumları ya da yardım aldıkları sivil toplum kuruluşları değil; kendi sosyal ağları aracılığıyla ulaşılmıştır. Bu ağlar içerisinde özellikle Düzce Üniversitesi’ndeki Arapça konuşan öğrenciler, öğretmen arkadaşlarımızın velileri, şehirde faaliyet gösteren tercümanlar ve kamusal alanlarda karşılaşmalar önemli rol oynamıştır. Bağımsız bir aracı ile ya da aracısız ulaşılan kişiler diğer kişilerle bizi tanıştırmış, böylelikle kartopu yöntemi şeklinde ilişki ağımız açılmıştır.

Bu araştırmada Iraklı, Afgan, Suriyeli ve İranlı dört farklı tercüman ile çalışılmıştır. Yapılan görüşmelerin, görüşülenlere zarar vermeme ortak ilkesi 
çerçevesinde anonimleştirerek kullanılmasına özen gösterilmiştir. Bu yüzden görüşülenlerin kimlik bilgilerini açık edecek isim, ikamet adresi ya da benzer bilgilere yer verilmemiş ve takma isimler kullanılmıştır. Ayrıca görüşülenler için hassas ya da onlara travma yaşatacak sorular sorulmamaya özen gösterilmiştir. Görüşülenlere araştırma konusunda gerekli açıklamalar yapılarak, katılımlarının tamamen gönüllülük esasına dayalı olduğu hatırlatılmış ve sözlü onayları alınmıştır. Görüşmecilerin kendilerini rahat hissedecekleri mekânlarda, genellikle evlerinde ya da dışarıdaki kafelerde tercüman aracıl1ğıyla ortalama bir saat süren söyleşiler yapılmıştır Çok az sayıda görüşülen ile örneğin Afgan gençlerle doğrudan Türkçe görüşme yapılmıştır Yarı yapılandırılmış bir soru rehberi temel veri toplama aracı olmakla birlikte, kısmen gözlemlerde de bulunulmuştur.

\section{Bulgular}

\section{Uydu Kente İlk Geliş ve Kayıt Süreci}

Sığınmacıların Düzce uydu kentine gelişi Ankara'da BMMYK'nın uygulama ortağı olan Sığınmacı ve Göçmenlerle Dayanışma Derneği (SGDD, yaygın olarak İngilizce baş harflerinden oluşan ASAM olarak bilinir) Ankara ofisine yaptıkları başvuru sonrasında yapılmaktaydı. Suriyeli olmayan sığınmacılar ASAM'a başvurularını yaptıktan sonra uydu kent olarak Düzce'ye gönderilmektedir. Ancak yeni uygulama ile 10 Eylül 2018 tarihinden itibaren tüm başvuruların Göç İdaresi Genel Müdürlüğü (GİGM) tarafından alınmaya ve BMMYK tarafindan yapılan mülteci statüsü belirleme (Refugee Status Determination-RSD) görüşmelerinin GİGM personeli tarafindan yapılması beklenmekteydi (UNHCR, 2018). Öte yandan BMMYK ve uygulama ortaklarının, Türkiye'deki uluslararası koruma başvuru ve statü sahiplerine danışmanlık ve koruma hizmetleri vermeye devam edeceği açıklanmıştır.

Sakarya ve Bolu gibi çevre illerde ASAM şubeleri bulunmakla birlikte Düzce'de ASAM gibi BMMYK ile çalışan sivil toplum kuruluşu bulunmamakta, dolayısıyla Düzce'ye geldiklerinde sığınmacılar için ilk adres İl Göç İdaresi Müdürlüğü (İGIM) olmaktadır. Burada geçici kimlik belgesi alabilmek için ayrıca kayıt yaptırmaları gerekmektedir. Bu kimlik belgesi sığınmacıların resmi işlemlerini yapmaları ve eğitim, sağlık gibi sosyal haklara erişebilmeleri için hayati öneme sahiptir. Özellikle kimliği olmayan sığınmacıların 
daha fazla sorun yaşadıklarını söyleyen İGİM Çalışanı C, "Kimliği olmayan şahıs biraz sıkıntı yaşıyor, doğalgaz kurumuyla biraz sıkıntı kimliği yok diye açmıyor işte hastanede sıkıntı yaşayabiliyorlar ameliyat olamıyorlar. Sadece tedavi olabiliyorlar" şeklinde yaşadıkları sorunları dile getirmiştir.

Uluslararası koruma başvurucuları için kayıtta herhangi bir fotoğraflı kimlik belgesi, Düzce'ye yaşadıklarını gösterir bir belge ve fotoğraf istenmektedir. Kimlik belgesi olmayan sığınmacılar da başvuru yapabilmekte, bu başvurularda beyan esas alınmaktadır. Başvurusunu yapan ve geçici kimlik kartını alan sığınmacılar, "uluslararası koruma başvurucusu" statüsünde kabul edilmektedir. Geçici kimlik belgeleri altı aylığına verilen başvurucular daha sonra mülteci statüsü belirlemek için İGIM tarafından mülakata çağrılmaktadır. Eğer mülakatları olumlu geçerse "şartlı mülteci" statüsüne hak kazanmakta ve üçüncü ülkeye yerleştirilene kadar Düzce'de yaşamaları beklenmektedir. Ancak Geçici Koruma sistemi altındaki Suriyeliler için başka bir süreç işlemektedir. Suriyeliler, eğer başka yerde bir ilde kayıt yaptırmadılarsa, Düzce İl Emniyet Müdürlügü Yabanc1lar Şube’ye kayıt yaptırarak geçici kimlik belgelerini yaklaşık bir ay içinde alabildikleri söylenmiştir.

Sığınmacıların başvurusu sırasında yapılan görüşmelerde tercümanın deneyimli olması, sığınmacıların karşılaştıkları ve toplumsal cinsiyete özgü risklerin farkında olması önem taşımaktadır. Bu yüzden uluslararası başvurularda sığınmacıların tercümanın cinsiyetini seçme hakkının tanınması tavsiye edilmektedir. Düzce'de de İGIM Çalışanı C, kadın ya da erkek tercüman tercihini sorduklarını ancak her zaman isteklerini yerine getirmenin mümkün olmadığını söylemiştir. Aynı görüşülen, tercüman bulamadıkları için "doğru olmamakla birlikte" uluslararası koruma başvurucuları arasından tercüman çalıştırdıklarını söylemiştir.

Normalde çok olmaması gerekiyor ama mecburen, bulamadığımız için uluslararası koruma başvuru sahiplerinden bir tane tercümanımız var. ... Genelde bayan tercüman kullanıyoruz, biz devraldıktan sonra [Yabancı Şube'den] hep bayan tercümanla çalıştık. ... Tercümanlar bizim gibi bakamıyor, profesyonel olamıorlar. Biz de bu konuda böyle bir şey görürsek ya mülakata ara veriyoruz ya da mülakat bitiminde kendisine söylüyoruz (İGiM Çalışanı C).

Tercümanın gerekli eğitimleri almaması özellikle sığınmacıların kişisel bilgilerinin üçüncü taraflarla paylaşılması ya da aleyhine kullanılması gibi 
farklı riskler barındırabilmektedir. Nitekim sığınmacılarla görüşmelerimiz de bu çerçevede özellikle tek yaşayan kadınlar için bu bilgilerin çok önemli olduğunu göstermektedir.

Bazı sığınmacılar yerleştirilmeden önce Düzce'yi ziyaret ettiklerini ya da kentte bulunan akraba ve sosyal ağları aracılığıyla Düzce hakkında bilgi sahibi olduklarını söylemişlerdir. Düzce'yi tercih sebebinde kentin sosyal yapısının etkili olduğu görülmektedir. Örneğin Iraklı bir sığınmacı olan Mahsun (34) tercih sebeplerini söyle açıklamaktadır:

Buradaki insanlar da bizim gibi. Açık değiller [İslami olarak kadınların örtünmesine dair bir gönderme] ve daha çok bizim gibi aileler var. Gençler daha başka illerde ama Düzce'de daha çok aileler var. Düzce iyi dediler. İnsanlar güzel ahlaklı dediler. (Mahsun, 34, Irakl1).

Sosyal ağlar göçmen ve sığınmacılar için yeni bir hayata başlamanın risklerini azaltıcı hayati öneme sahiptir. Örneğin Düzce'ye geldiğinde hiçbir tanıdığı olmayan Iraklı kadın sığınmacı Cemile ilk gece sokakta kaldığını, daha sonra bir hafta boyunca ona yardım eden Iraklı bir ailenin evinde kaldığını söylemiştir.

Bir tercüman var o bana çok yardım etti, iş buldu bana tek odalı küçük bir ev buldular, battaniye getirdiler. Çalışıı ama daha sonra çok hasta oldum. İki ay evin faturasını ödeyemedim elektrik eksildi. Kar var çok hasta oldum, insanlar bana yardım ettiler hem Türk hem Iraklılar. Onları aradım ziyarete geldiler, baktılar durum çok kötüydü beni acile aldılar, ilaç aldılar, elektrik faturasını ödediler, açtılar soba taktılar (Cemile, 46, Irakl1).

Sığınmacılar, İl Göç İdaresi’nde karşılaştıkları tercümanlardan, Düzce'de yaşayan tanıdıklarından ya da genel olarak kendi topluluk üyelerinden ilgili kamu kurumları hakkında bilgi almakta ve ev bulma konusunda destek görmektedirler. Örneğin eşi ve çocuklarıyla birlikte Irak'tan Düzce'ye gelen Lina (34) eşinin bir camide Iraklılarla tanıştığını ve onlar aracılığıyla ev ve iş bulduğunu söylemiştir.

\section{Barınma Koşulları ve Yüksek Kiralar}

Hem uluslararası koruma hem de geçici koruma altındaki sığınmacıların kendi barınma olanaklarını yaratmaları beklenmektedir. Kısıtlı düzeyde ve bireysel inisiyatiflerle bazı yerel idare yöneticilerinin ve STK'ların yeni gelen ve çok çocuklu ailelere ücretsiz ya da düşük kiralarla barınma imkânı sağla- 
dığı söylenmiştir. Ancak çoğu sığınmacı kent merkezinde sağlıksız evlerde ve yüksek sayılabilecek kiralarla kendi başının çaresine bakmaya çalışmaktadır.

Görüşülenlerin barınma koşullarına bakıldığında büyük kısmının kent merkezinde, depremden etkilenmiş hasarlı binalarda ya da depremden etkilenenlerin kendileri için yaptıkları geçici barınma yerlerinde kaldıkları görülmektedir. Küçük çocuk ve bebeklerin de yaşadıkları bu yapıların genellikle bakımsız, karanlık, nemli ve soğuk, 1sınma sistemi ve izolasyonu olmayan, sobalı, banyosuz ve genel olarak insan yaşamına uygun olmayan sağlıksız yapılar olduğu gözlemlenmiştir. KADİM Çalışanı A sığınmacıların kimsenin tercih etmediği yapılarda ve normal binalarla eşdeğer kiralar verdiklerini -ortalama 500-800 TL arasında- ve bazı mahallelerde yoğunluklu olarak yaşadıklarını belirtmiştir. $\mathrm{Bu}$ mahalleler özellikle İl Göç İdaresi'ne yakın yerlerde yoğunlaşmaktadır. Bunun en önemli sebebinin ise iki haftada bir İGIM'e giderek imza atma zorunluluğu ve yol parası vermekten kaçınmak olduğu anlaşılmaktadır.

Kötü ve sağlıksız koşullarda barınan sığınmacılar toplumsal ayrımcılıktan kaynaklı olarak ev bulamamak, yüksek kiralar, faturaları ödeyememe riski ve güvenlik sorunları ve komşularla ilişkiler konusunda da sorun yaşamaktadır. Örneğin rutubetli bir evde elektrik sobası ile 1sınmaya çalışan Iraklı Zeynep (30) ile görüştüğümüz Ekim 2017'de her ay 500 TL kira verdiğini ve 1sınmak için 100-150 TL elektrik faturası ödediğini söylemiştir. "Güneş olunca dışarı ç1kıyorum” diyen Iraklı Zeynep düzenli tek gelirinin Kızılay Kart’tan alacağı 120 TL'lik aylık maddi destek olacağını ve bunun kirasına bile yetmediğini ifade etmiştir. Astım hastası olan Lina (34) ise dört çocuğu ile birlikte deprem sonrası yapılan derme çatma geçici bir barınakta kalmaktaydı. Özellikle yağmur yağdığında nem yapan evde kömür sobası ile ısınmaya çalıştıklarını söyleyen Lina, evin yıkılmak üzere olduğu için ev sahibinin çıkmalarını istediğini söylemiştir.

Ev sahiplerinin Iraklı ya da Suriyeli sığınmacılara evlerini kiralamak istememeleri sıklıkla karşılaşılan bir durumdur. Bu isteksizliğin genellikle kalabalık aileler ya da farklı kültürler bahane edilerek meşrulaştırıldığı görülmektedir. Görüşülen Iraklı sığınmacı Mahsun (34) önce ev sahiplerinin evlerini vermek istemediklerini ancak tanıdıkları aracılığıyla ev bulduklarını belirtmiştir. Benzer şekilde Iraklı bir sığınmacı Raşid (24) ise tek kalan erkeklerin özellikle ev bulmakta zorlandıklarını şöyle ifade etmiştir: 
Benim bir arkadaşım vardı. Ev arıyordu. Arap olduğu için vermeyen çok oldu. Dün Uzunmustafa'ya gittim. Ev sahibi tek başına kalacaksan ev vermem dedi. Ailenle birlikte burada kalacaksan bu evi veririm dedi. Mesela, kiralık ilanları olan evlerin üzerindeki numaraları ara, Arap olduğun için sana vermezler. Şimdiki oturduğumuz ev sahibi çok iyi. Bu evde bizden önce bir Suriyeli oturuyordu. Evden çıkacağını bize söyledi, biz de gittik ev sahibiyle konuştuk. Kabul etti. Hiçbir sorun yaşamıyoruz (Raşid, 24, Iraklı).

Suriyeli sığınmacı Asaf (65) ise ev sahiplerinin evde misafir dahi istemediğini ve ev bulmakta zorlandıklarını söylemiştir. Ev sahiplerinin isteksizliği ve ayrımcı tutumları çoğu sığınmacıyı aracılara, yani emlakçılara, başvurmaya itmektedir. Bu da emlakçıların fahiş kiralarla sığınmacılara ev vermesi, yüksek depozito istemesi ya da keyfi olarak evden çıkarmaya çalışmasıyla sonuçlanmaktadır. Emlakçılarla sık yaşanan sorunlar Düzce Valisi'ni emlakçılarla görüşmeye kadar götürmüştür. İGIM Çalışanı $\mathrm{C}$, bu durumu şöyle aktarmıştır:

... emlak fiyatlarında sıkıntı oluyordu. Geçen duyduğumda [Düzce Valisi] emlakçılarla görüşecekti, onlarla artık nasıl konuşma yapar onun takdiri. Biraz daha Düzce'de iyi durumlar, yani birçok şehre göre müdahale edilebiliyor. İnsanlar şikâyet merciini kullanabiliyorlar, çok rahat Düzce'de. ... Valiliğe gidiyor, belediyeye gidiyor, emniyete gidiyor, savcıllğa gidiyor, bize geliyor. (IGIMM Çalışanı C).

Ancak görüşmeler sığınmacıların karşılaştıkları sorunları bile ev sahiplerine ya da komşularına söylemeye çekindiklerini göstermektedir. Örneğin Irak11 Muhammed mahallede karşılaştıkları sorunu şöyle aktarmıştır:

Bir süre önce bir kavga çıkmış mahallede birisi de silah çekip havaya sıkmış. Biz evdeyken çıkamadık, hem de kendi evimizin kapısını da kırdılar ama çıkıp sormadık neden kapıyı kırdınız diye. Komşularla konuşamadık, ilişkimiz yok, hatta bu kapıyı neden kırdınız diye sorarsam bize evden çıkın derler diye soramadık. Ev sahibi yakın oturmuyor. Yedi aydır yeni evde oturuyoruz ama çok iyi değil başka ev bakıyorum. Biraz daha merkezde bakıyorum ama burada vermezler bize. Suriyeli aile var, diyor ki Suriyelilere vermiyor (Muhammed, 23, Irakl1).

Görüşülen sığınmacıların yüksek kiraları ödeyebilseler dahi 1sınmak için kullandıkları doğalgaz, soba için yakıt ya da elektrik faturalarını ödemekte zorlandıkları anlaşılmaktadır. Nitekim kazançlarının büyük bir kısmını ev kirasına harcayan sığınmacılar ciddi bir geçim sorunu yaşamaktadır. Yüksek kiralar ile baş edebilmek için sığınmacılar, kalabalık bekâr evlerinde yaşamak ya da birden fazla ailenin aynı evde kalması gibi stratejiler geliştirmek zorunda kalmaktadırlar. Bu durum da ev sahiplerinin kalabalıktan ya da gürültüden şikâyetçi olması ve sığınmacıların yeni bir ev arayışı ile sonuçlanabilmektedir. 


\section{İşgücüne Katılım ve İstihdam Olanakları}

Barınmaya paralel olarak geçim sıkıntısı da Düzce'de çoğu sığınmacının önemli sorunlarından birisidir. Daha önce açıklandığı gibi, Türkiye'de sığınmac1ların çalışma izni ancak koruma başvuru tarihinden altı ay sonra ve işveren tarafindan yapılan başvuru ile olabilmektedir. Ancak işverenler hem ödemek zorunda oldukları harçlardan hem de daha ucuza işçi çalıştırmak isteklerinden dolayı sigorta yaptırmak konusunda isteksizdir. İGİM Çalışanı C, sığınmacıların izinlere erişiminin zor olduğunun ve müsamaha gösterilmesi gerektiğini vurgulamıştır:

İşverenin çok işine gelmiyor çalışma izni almak çünkü belli şartlar gerektiriyor, bu da bir maliyet. ... Çalışmazsa insan nasıl geçinecek, başka yönlere başvuracak yani kötü yönlere başvuracak yani bu yüzden biraz da müsamaha gösteriliyor. Benim görüşüm, devlet olarak da biraz müsamaha gösterilmesi, şimdi herkese çalışma izni verirseniz bu sefer bizim vatandaşımız mağdur oluyor ... biraz orta yol bulmak gerektiği için müsamaha gösteriliyor (İGìM Çalışanı C).

Hayatlarını idame ettirebilmek için sığınmacılar enformel emek piyasasında kayıt dışı çalışmak zorunda kalmaktadırlar. Başka bir ifade ile bir yandan izinsiz çalışma ve sınır dışı korkusu yaşayan sığınmacıların diğer yandan çalışmaktan başka bir düzenli gelire erişim seçeneği bulunmamaktadır. Burada belirtmek gerekir ki izinsiz çalışma durumu özellikle uluslararası koruma rejimi altındaki sığınmacılar için sınır dışı edilme sebebi olabilmektedir.

Net bir rakama ulaşamasak da, yapılan görüşmeler sırasında çalışma iznine sahip hiçbir sığınmacıya rastlanmaması Düzce'de de göçmen ve sığınmacılar için alınan çalışma izinlerinin sayısının oldukça düşük olduğunu göstermektedir. Erkek sığınmacıların daha çok fiziksel güç gerektiren inşaat işlerinde, hayvan çiftliklerinde, nakliye sektöründe hamallık işlerinde, araba yıkama işinde yevmiyeli olarak çalıştıkları gözlenmektedir. Kentte sadece telefoncu, lokanta, berber ve kafe gibi birkaç küçük işletme, göçmen ve sığınmacılar tarafindan işletilmektedir. Kadın sığınmacıların işgücüne katılım açısından erkeklere göre daha dezavantajlı olduğu görülmektedir. Bunun göstergelerinden birisi olarak görüşülen hiçbir kadın sığınmacının düzenli bir işe sahip olmadığını not düşmek gerekir. Kadın sığınmacılara Düzce'de nasıl geçindiklerini sorduğumuzda tercüman olarak çalışan bir kişi hariç hiçbiri düzenli çalıştıkları bir işe sahip olmadığını söylemiştir. Düzensiz yapılan işler arasında işyeri ve ev temizliği, tekstil ve tatlı imalat atölyelerinde işçilik ve evde kuaförlük öne çıkmaktadır. 
Araştırma kapsamında görüşülen erkek sığınmacılar da iş bulma konusunda çok zorluk yaşamadıklarını söylemişlerdir. 1999 yılında depremle büyük kısmı yıkılan Düzce'de inşaat sektörünün güçlü olması erkek sığınmacılar için daha kolay işe erişim olanaklarını beraberinde getirmektedir. Ancak s1ğınmacı erkekler düşük ücret ve ücretini alamama sorunu ile sık karşılaştıklarını dile getirmişlerdir.

Çilimli'de bir tekstil atölyesinde iki ay çalışıım. Bir arkadaşım orada çalışıyordu. Onun yanına gittim. 1500 lira vereceklerini söylediler. Ama maalesef paramı alamadım. Paramı vermedikleri için ayrıldım oradan. Sekiz Iraklı çalışıyorduk. Hiçbirimizin parasını vermediler. Para istemeye gittiğimizde patron siz iyi çalışmıyorsunuz size para yok dedi. ... Patronun yanına gittim, polise şikâyet ederim dedim. Git şikâyet et. Bir şey olmaz sen Arapsın zaten sigortan da yok, şimdi s.ktir git dedi. ... Birçok arkadaşım, tanıdığım çalıştı parasını alamadı ya da geç aldı. Haftalık anlaşıyorsun Cuma günü paranı alırsın diyorlar. Ama hep geciktiriyorlar. (Kamran, 27, Irakl1).

Afgan sığınmacı Reza hem bulaşıkçı olarak hem de inşaatlarda çalıştığını ancak parasını alamadığını şöyle anlatmıştır:

XCafe'ye girmeden bir hafta yemekhanede çalışım, aşçı sipariş olunca geliyordu. Bir hafta bulaşık yıkadım ama para vermediler. Bir hafta param kaldı. İnşaatta da öyle. İzinli günlerimde inşaatta çalışıyorum, vasıfsız işler çırak gibi çalışıyorum, bana 70 lira veriyorlardı ama paramı vermediler, 530 Lira param kaldı. Öğrencilerden yardım istedim ama bir şey olmadı (Reza, 18, Afganistanlı).

Sığınmacıların işyerlerinde uğradıkları haksızlıklardan dolayı hukuksal sürece başvuramamalarının en önemli nedeni sigortasız, "kaçak" çalışmalarıdır. İGİM Çalışanı C şöyle açıklamıştır:

Erkeklerin çoğu iş bulamazsa inşaata gidiyor. İnşaat zaten Düzce'de çok yüksek. ... Kişi beğenmeyebiliyor işi bazen de tabi ki yerli halk da parasını vermiyor. Parasını vermediği için zorlanıyor yani hiç bir yerden geliri olmayan insan çalıştığı yerden para alamayınca da hayat şartları zorlaşıyor. ... Bize başvuran yok çünkü biz başvuru mercii değiliz karakola gitmeleri gerekiyor ama bu durumda hiçbir şey iddia edemiyorlar, çalışma izni almaları gerekiyor (İGiM Çalışanı C).

İGIM Çalışanı, parasını alamama gibi durumlarda çok fazla müdahale edemediklerini söylerken KADİM Çalışanı A, bazı durumlarda STK'lar aracılığıla işvereni arayarak arabuluculuk etmeye çalıştıklarını söylemiştir. Düzce Barosu'na da bu tür haksızlıklara karşı başvuru yapıldığı söylenmiştir. Özellikle sigortasız işçi çalıştırma ve iş kazaları konularında Baro'nun avukat desteği 
sağladığı belirtilmiştir. Nitekim Düzce İGIMM Çalışanı $\mathrm{C}$ de bazı başvurucuları Baro'ya yönlendirdiklerini ifade etmiştir. YUKK'un 81. Maddesinde, avukatlık ücretini karşılama imkânı bulunmayan uluslararası koruma başvuru sahibi ve uluslararası koruma statüsü sahibi kişinin, 1136 Sayılı Kanunun adli yardım hükümlerine göre avukatlık hizmetinden faydalanabileceği belirtilmiştir. Özellikle idari gözetim altında tutulan veya uluslararası koruma başvurusu reddedilen mülteci ve sığınmacıların yargı yoluna başvurabilmeleri için, yine 1136 sayılı Avukatlık Kanunu'na atıf yapılarak, avukatlık hizmeti sağlanabileceği ifade edilmiştir. Bu hizmetlere geçici kimlik kartına sahip olan Suriyeli sığınmacıların daha rahat erişebildikleri ancak Suriyeli olmayan sığınmacılara ve göçmenlere Baro avukatlarının inisiyatif alarak danışmanlık yaptığı belirtilmiştir.

Haksızlıklarla baş edebilmek için sığınmacılar arkadaşları, akrabaları gibi güvenilir kanallar üzerinden iş aramakta, piyasadan daha düşük ücret bile olsa tanıdıklarının çalıştığı ve ücretini alma garantisi olan işyerlerinde çalışmaya özen göstermektedirler.

Iraklıların bir özelliği var. Biri iş arıyorsa birine söyler, o diğerine söyler. Bende bu işi böyle buldum. Bir arkadaşımın tanıdığı çalışıyordu bu fabrikada (pişmaniye üretim atölyesi), patronuna söylemiş beni. Gelsin başlasın demiş o da. Ertesi gün gittim, konuştuk, anlaştık hemen başladım işe (Raşid, 24, Iraklı).

Sığınmacıların çalışma deneyimleri geçimlerini sağlamak için her türlü ağır çalışma koşullarına razı geldiklerini göstermektedir. Güvencesizlik, sığınmac1 emeğinin işverenler tarafından acımasızca sömürülmesine yol açmanın yanı sıra bir 'vasıf israfina' da sebep olmaktadır. Ekiz Gökmen (2011), Marmaris'te yaptığı araştırmasında eğitimli göçmen kadınların turizm sektöründe masöz, animatör, tercüman, tur operatörü ya da temizlikçi gibi düşük statülü ve düşük ücretlerle çalıştırılarak "niteliksizleştirildiklerini” ortaya koymaktadır. Benzer şekilde Üstübiçi Önay (2009) da ev içi hizmetlerde ve ticari seks endüstrisinde çalışan göçmen kadınların kötü çalışma koşullarına ve vasıf kaybına dikkat çekmektedir. İkamet ve çalışma izinlerine erişimin zorluğu, sınırdışı edilme korkusu gibi faktörler göçmenlerin bu işlere razı geldiklerini göstermektedir. Lordoğlu ve Aslan da (2015) ülkelerinde iyi eğitim görmüş bazı Suriyeli sığınmacıların Türkiye'de "beyin israfına" uğradıklarını göstermektedirler. Bu araştırmada da yüksek eğitimli sığınmacılar ile karşılaşılmıştır. Örneğin yüksek lisans seviyesinde eğitim almış olan Baki (32) çalışma deneyimini şöyle anlatmaktadır: 
$X$ İngilizce kursunda yaklaşık iki yıldır çalışıyorum. ... Sigorta ödemek istemiyorlar. Bana daha az ücret vermek için yapıyorlar bunu. Bana saat başı ücret vermek istiyorlar. Örneğin bugün dört saat dersin var, o kadar ücret, dersin olmadığı zaman para vermeyecekler. Şunu biliyorlar, oradan başka bir yere gidemem. Herhangi bir yere şikâyette bulunamam. Fabrikalara gittim. İşçi olarak çalışmak istediğimi belirttim. Tamam git Valilikten çalışma izni al dediler. Valiliğe gittim, hayır bu izni sen alamazsın, fabrika alacak dediler. Benimle bir top gibi oynadılar. O ona gönderdi, o ona gönderdi. Ben de vazgeçtim (Baki, 32, Irakl1).

Burada KADİM'in göçmen ve sığınmacıların mevsimlik işçi olarak çalışması için İŞKUR, Ensar-Muhacir Derneği ve Erdemler Derneği gibi STK'larla sığınmacıların fındık toplama gibi mevsimlik işlere yerleştirilmesini sağlayan "Kardeş Aile Projesi” adıyla ortak bir çalışma yürüttüklerini fakat yeterince başarılı olamadıklarını KADİM Çalışanı A, şu şeklide ifade etmektedir:

Ailelerle ilgili şöyle bir anlaşmamız var; dönemsel olarak işlerine çalışacaklar ama hem çalıştıktan sonrada -maneviyattan dolayı çalışmadığı dönemdeev kirasını ve gıdasını üstlenecek. Bu da 750 lira, dört-beş ay ona dokunmayacaksınız, yardımsever aile [sığınmacı ailenin yanında kaldığı işveren aile] karşılayacak ama siz de altı ay boyunca bu kişinin findığının dalını keseceksiniz. O [sığınmacı] çalıştığı zaman sadece 60 lira günlüğünü alacak. ... Mevsimlik işçiler zaten her dönem çalışamaz. ... İşsiz kaldıkları dönemde de ev kirası ve gıda yardımı yapılsın dedik. Ama motosiklet almış, dediğim gibi insanların hep daha iyiyi istemesi bizleri de hayal kırıklığına uğratıyor. ... Yani biz bir aileye denedik, iki-üç aile planlamamız vardı vazgeçtik. Olumsuz örnekler çevrede çabuk duyuluyor. ... biz zaten deneme amaçlı aldık o yüzden şöyle yaptık yevmiye sistemi çalıştırdık, gelen parasını alır, gelmeyen de en azından ortalıkta gözükmez ona da kimse bir şey demez. (KADİM Çalışanı A)

KADİM'in girişiminde ve Erdemler Derneği üyeleri aracılığıyla 2017 yılında 60 sığınmacı için mevsimlik işlerde İşkur ve Valilik’ten alınan muafiyet belgesi ile çalıştığı söylenmiştir. Ancak KADİM Çalışanı A, bu projenin de çok başarılı olamadığını, sebebinin ise "findık toplamayı bilmedikleri için başarılı olamadık ama yüzde 50 devam eden ekibimiz oldu" şeklinde açıklamıştır. Dedeoğlu (2018) tarafından yapılan çalışma Türkiye'de mevsimlik gezici tarım işçiliğinin (MGTí) toplumun en yoksul kesimleri tarafından yapıldığına ve Suriyeli sığınmacıların mevsimlik tarım işlerinde istihdamlarının artması yerli işgücü ile rekabetin artmasına yol açacağına işaret etmektedir. 
Bu durumu "yoksulların rekabeti” olarak adlandıran Dedeoğlu'nun çalışmasına paralel olarak Düzce'de de sığınmacıların normal yevmiyelerden daha düşük ücret aldıkları görülmektedir. Burada belirtmek gerekir ki sığınmac1ların işgücüne eşit katılımı farklı yasal statülerinden ve toplumsal cinsiyetten de etkilenmektedir. Örneğin Suriyeliler, tarım ve hayvancılık gibi mevsimlik işlerde çalışmak için Düzce'den verilmiş geçici koruma kimliği ile İŞKUR'a müracaat ederek çalışma izni muafiyet belgesini daha kolay alabilmektedirler.

İşgücüne katılımda kadın sığınmacılar ise hem iş bulmakta zorlanmakta hem işlerin niteliği açısından toplumsal cinsiyete dayalı işlere mahkûm olmakta hem de işyerinde cinsel taciz gibi toplumsal cinsiyete dayalı risklerle karşılaşmaktadırlar. Yaşları ortalama 30 olan görüştüğümüz kadın sığınmacıların hemen hepsi orta öğretim (ilk ve orta) mezunudur. Mesleki sertifikası olan iki kadın dışında çoğu daha önce çalışmadıklarını söylemişlerdir. Meslek anlamında görüşülen sığınmacı kadınların üçü düzensiz olarak kuaförlük ya da güzellik uzmanlığı yaptığını, birisi tercüman olarak çalıştığını, birisi de arada temizlik yaptığını söylemiştir.

Kadınlar da pek çok sığınmacı gibi kayıt dışı ve güvencesiz çalışmak durumunda kalmaktadır. Bu güvencesizlik ve sınır dışı edilme riski sadece düşük ücret ve ağır çalışma koşullarını değil aynı zamanda cinsel tacize uğrama riskini de artırmaktadır. Görüştüğümüz sığınmacı kadınlar buldukları işlerde kötü çalışma koşulları, sağlık sorunları ve cinsel taciz gibi sebeplerle uzun süre çalışamadıklarını ifade etmişlerdir. Örneğin daha önce bir şirkette çay ocağında çalıştığını söyleyen Zeynep (30) bu işinden Türkçe bilmediği için ayrıldığını, ancak daha sonra patronun cinsel tacizine uğradığını söylemiştir. Yalnız yaşadığı için özellikle Iraklı topluluktan erkekler tarafından da rahatsız edildiğini de söyleyen Zeynep iş ararken tacize uğradığını şöyle ifade etmiştir: "Bir adam var, iş istedim, bana iş bul dedim o da bana kız bul dedi. Ona bulamam dediğimde de sen varsın ya dedi."

Tek kalan sığınmacı kadınlar ya yurtdışından ailelerinin gönderdiği parayla ya yardımlar ya da düzensiz işlerle yaşamlarını sürdürmektedirler. Haftada bir gün işyeri ve apartman temizliği yapan Cemile de iki kızı ve kendisi için Kızılay Kart'tan aldıkları aylık 120 Lira ve etraftakilerin yardımı ile geçindiklerini söylemiştir. Görüştüğümüzde bir şekerleme fabrikasında iş bulduğunu söyleyen Zeynep (30) de hiçbir geliri olmadığını ve yeni Kızılay Kart aldığını ancak kira ve faturaları karşılamak için bu paranın yetmeyeceğini ifade etmiştir. Lina da 
benzer şekilde yeni aldığı Kızılay Kart dışında hiçbir geliri bulunmadığını ve ailevi sebeplerle Irak'a giden eşinin Türkiye'ye giremediği için on aydır eşinin yurtdışından gönderdiği kısıtlı para ile geçimi sağlamaya çalıştığını belirtmiştir. Sağlık sorunlarından dolayı ağır bir işte çalışamadığını ve evde kuaförlükle geçindiğini söyleyen Dilan çalışma koşullarını şöyle ifade etmiştir:

Denedim, bir tatlı fabrikasında çalışmaya başladım. Üç hafta çalıştım dayanamadım çok hasta oldum ve aldığım para hep doktora gitti. Sabah 7 akşam 6 çalışıyorduk. Sabah saat 10 'da bir de öğleden sonra 3'te 10 dakika mola ayrıca 15 dakika yemek molası veriyorduk. Hep ayakta duruyorduk sadece el hareketi yapıyorduk, şeker dolduruyorduk. Benim sırtımda rahatsızlık var dayanamıyordum. Şimdi ancak evde çalışabilirim. Çalıştığım zaman yaşayabilirim ama çalışmadığım zaman param yok ki, en büyük sıkıntı o. ... Burada sadece Kızılay Kart alıyorum, 500 TL kira ödüyorum. (Dilan, 32, Iraklı)

Kayıt dışı çalışmak, çoğu zaman emeklerinin karşılığını alamasalar da s1ğınmacılar için kaçınılmazdır ve bu kaçınılmazlık sığınmacıları daha kırılgan bir konuma itmektedir. Bu gruplar bir "yabancı" olarak kayıt dışı çalışmanın yanı sıra toplumsal cinsiyet eşitsizliğinden ve deneyimsizlikten de etkilenmektedirler. Bu kırılganlıkları kadınların işyerlerinde sıklıkla cinsel tacize uğramaları ile kendini gösterirken, Afgan gençler ise sıklıkla paralarını alamamaktan şikâyet etmektedirler. Çoğu lise mezunu olan ve iyi Türkçe konuşan bu gençlerin gelecek planları arasında üniversitede okumanın da bulunduğunu belirtmek gerekir. Geçici kimlik kartlarını kısa zamanda alamamaları ve uzun saatler çalıştıkları için akademik Türkçelerini geliştiremeyen Afgan gençler, inşaatlarda düşük ücretli vasıfsız işçi, kafelerde garson ya da bulaşıkçı olarak çalışmaktadır. Afgan gençler için yüksek öğrenime erişimlerini sağlayacak özel bir danışmanlık ve destek programı ihtiyacı hissedilmektedir.

\section{Sağlığa Erişim ve Tercüman Engeli}

Sağlık hizmetlerine erişim sığınmacılar için en önemli sosyal destek hizmetlerindendir. Savaşın travmasından ve zulümden kaçan sı̆̆ınmacıların, içinde yaşadıkları kötü barınma, beslenme ve çalışma koşullarının da etkisiyle ortalama bir vatandaştan daha sık sağlık hizmetlerine erişim ihtiyacı duydukları söylenebilir. Sağlık konusunda sığınmacıların hepsinin sosyal güvenlik sistemine kayıtlı olmadıklarını ve olanların ise devlet hastanesine gitmeyi tercih ettiklerini belirtmek gerekir. 
Düzce'de hem Geçici Koruma hem de Uluslararası Koruma sistemlerine başvuranlar ücretsiz sağlik hizmetlerinden yararlanabilmektedir. Geçici Koruma kimlik belgesi sahiplerinin sağlık ve ilaç bedelleri AFAD tarafindan karşılanmaktadır. Yapılan görüşmelerde sığınmacıların geçici kimlik numaraları ile ücretsiz muayene olabilseler de tercüman ve ilaç masrafindan dolayı sağlık hizmetlerine erişemedikleri anlaşılmaktadır. Örneğin görüşülenler Arapça konuşan tercümanların hasta başına 20-30 TL ücret aldıklarını söylemişlerdir. Sığınmacılar bu ücreti verebilseler bile sınırlı sayıdaki tercümana uygun gün ve saati beklemek zorunda kalmaktadırlar. Nitekim Iraklı sığınmacı kadın görüşülenlerden olan Bibi (24) çok rahatsız olduğu zaman tercümanın işi olduğunu ve o gün doktora gidemediğini söylemiştir. Tercüman ücretini karş1layamayan görüşülenler ise ya doktora gitmemekte ya da başka yöntemlere başvurmaktadır.

Örneğin Zeynep (30) tercüman ücretini veremediği için Ankara'ya gittiğini, ASAM yol ücretini karşıladığı için ASAM'ın ücretsiz muayenehanesinde doktora göründüğünü ayrıca psikologla görüştüğünü söylemiştir. Ancak Zeynep ile görüştüğümüzde yaklaşık bir aylık reçetesini henüz eczaneden alamamıştı. Benzer şekilde bir başka görüşülen ise haftada bir defa Bolu'daki ASAM'a giderek oradaki psikologla görüştüğünü söylemiştir. Hem kendisinin hem de çocukların psikolojik desteğe ihtiyacı olduğunu vurgulayan Cemile (46) bu desteğin önemini "Orada birisi beni dinliyor" sözleriyle ifade etmiştir. Dilan da sağlık ile ilgili sorununu şöyle aktarmıştır:

Devlet hastanesine gittim ücretsiz muayene oldum ama ilacı parayla alıyorum. Hastane genel olarak sorunlu. Tercüman parası ve ilaç parası vermem gerekiyor. Sürekli ilaç almam gerekiyor, bazen pahalı geliyor. Bazen çocuğum yardım ediyor ama doktor için tercüman gerekiyor. (Dilan, 32, Irakl1)

Sığınmacı çocukların da özellikle sığınma süreci öncesine yaşadıklarının etkisinden kurtulamadıkları anlaşılmaktadır. Düzce'de üç yıldır karısı ve iki çocuğu ile kalan Kasım çocukların durumunu şöyle anlatmaktadır:

Çocuklar hiçbir şekilde Irak'a dönmeyi düşünmüyorlar. Evimizin bir odasına bomba geldi. Çocuklar pencereden bombanın gelişini bile izlediler. Bu yaşadıklarını hiç unutamıyorlar. Hala uykularında kabus görüyorlar. Konuşurken Irak muhabbeti geçince direk bu manzarayı hatırlıyorlar. Artık onlar için Irak bu... Türkiye'de kalmak istiyoruz ama o da zor. Biz insan haklarını burada bulduk. Irak 'ta can güvenliğimiz. Mal güvenliğimiz yoktu. Bizim umudumuz Türk pasaportu almak. Türk vatandaş1 olmak (Kasım, 36). 
Çocuklarının profesyonel bir psikolojik destek almadığını söyleyen Kasım (36) sadece öğretmenlerinin desteğiyle çocuklarının psikolojisinin yavaş yavaş düzeldiğinden bahsetmiştir. Keza, çocuklarından birisinin dışarıda oynarken düşen bir bombadan öldüğünü söyleyen Iraklı sığınmacı Mahsun (34) da diğer üç çocuğunun bundan etkilendiğini söylemiştir. Genel olarak sorun yaşayan sığınmacılar için Düzce'de psikolojik destek alabilecekleri bir yer bulunmamaktadır.

Sığınmacıların temel sağlık hizmetlerine erişimlerinde tercüman ve ilaç desteğinin yanı sıra sağlık kurumlarında istihdam edilen sosyal çalışmacı sayısının artırılması büyük önem arz etmektedir. Sığınmacıların hangi kurumlara nasıl erişebilecekleri ve nereden destek alabileceklerine dair doğru bilgiye erişimi hayati öneme sahiptir. Burada belirtmek gerekir ki, araştırmamızın raporu hazırlanırken KADİM öncülüğünde Arapça konuşan bir doktorun bulunduğu bir poliklinik hizmete başlamış ve Düzce Devlet Hastanesi'nde ücretsiz bir tercüman atandığı söylenmiştir.

\section{Gündelik Hayat ve Sosyal Dışlanma}

Sığınmacılar, yerli halk ile işyerlerinde, yaşadıkları mahallelerde, alışveriş̧ mekanlarında ve kamusal alanlarda karşılaşmalarına rağmen ciddi bir iletişimi içinde değildirler. Özellikle komşular ve okuldaki veliler birbirleri ile daha fazla iletişim kurmakla birlikte komşuluk, arkadaşlık ilişkileri dil engeli ve 'yabancı'/öteki algısı yüzünden sınırlı kalmakta, sığınmacılar 'sosyal dışlanmaya' maruz kalarak ‘ötekileştirilmekte'dirler. “Öteki”, bir ya da daha fazla kişi, kültür ya da toplum tarafından, geçmiş veya güncel ilişkiler referans alınarak, dikey (sınıfsal) ya da yatay (etnik vb.) olarak farklılaştırılmış ve ayrıştırılmış olan, kişi, grup, sınıf, halk vb. şeklinde tanımlanabilir. "Ötekinin/ ötekilerin” belirlenmesi toplumsal olarak işleyen bir süreçtir. Ötekileştirme sürecini, bir halkın veya bir grubun başka bir ya da daha fazla halk ya da grup hakkındaki soyut ve somut, tüm fikir hayal ve yargılarını içeren, gücünü toplumsal bellekten alan, içerisinde çoğu zaman damgalama süreçlerini de barındıran "imgeler” bütünü olarak tanımlayabiliriz (Nahya, 2011).

Düzce'deki göçmen ve sığınmacılar için "misafir", "yabancı" ve "Suriyeli" gibi ötekileştirici bir dil kullanıldığı gözlenmiştir. İGİM Çalışanı C dahi sığınmacıların hak talep ettikleri durumlarda ötekileştirici bir dil kullanmaktadır:

Çok misafirperver olduğumuz için bir de dinimiz gereği çok yardımseveriz. İnsa- 
nımız gerçekten onları mağdur olduğunu düşünerek yardım ediyor ... ama problem olmaya başladığı zaman, biraz da gerçekleri gördüğü zaman insanlar bazen soğuyabiliyor, bazen nefret edebiliyor, ülkemizi mahvettiler konumuna getirebiliyor. ... Ben de böyle misafirperverlik yönünden bakıyorum yani orda problemler yaşamışlar, gelmişler buraya ama buraya geldiklerinde -hepsi için konuşmuyorum ama - onların nankör olduğunu görünce af edersiniz yani bir antipati oluşuyor. Her şeyi beğenmeyebiliyorlar. ... Yani en basiti geçen hafta bize yazı geldi Suriyelilerle ilgili, şahsa durumu söylediğimizde en son Almanya'ya gideyim falan dedi yani. Düşünebiliyor musun yani çok farklı olaylar olabiliyor o zaman git, yani gelmeseydin. (İGì Çalışanı C)

Görüştüğümüz kamu çalışanları da benzer şekilde sığınmacılara "hayırseverlik", "misafirlik" ya da güvenlik açısından yaklaşmakta, insan hakları odaklı bir yaklaşım sergilememektedirler. Bu durum özellikle yerli halk ile ortaya çıkan çatışmalarda sığınmacılara olan tepkide kendini göstermektedir. Şahit olduğu bir olayı anlatan Suriyeli Hasibi (32), haksızlıklara karşı sığınmacıların kendilerini savunamadıklarını söylemiştir:

İki gün önce bir olay oldu burada. Suriyeli birisi bir iş yapmış. Adam parasını vermemiş. O da parasını istedi. Kavga çıktı. Adam para vermemek için Tayyip Erdoğan'a küfür etti diye iftira attı adama. Şimdi insanlar geri dönmeye başladı yavaş yavaş. Bizim memlekette hayat ucuz, kimse karnı aç yatmaz, ama burada yatar. Başka memleket çünkü. Orda aile var, akrabalar var. Burada kim sana veriyor yemek. (Hasibi, 32, Iraklı)

Türkiye'deki ikili sığınma sistemi, Suriyeliler, Suriyeli olmayanlar ve kağıtsızlar olarak farklı statülere bağlı kurumsal bir ayrımcılığa yol açmaktadır. Nitekim görüşmelerimiz ve gözlemlerimiz sağlık, eğitim ve emniyet gibi çoğu kamu kurumunda, mevzuattan da kaynaklı olarak Suriyeli olmayan sığınmac1lara daha az tolerans ve daha fazla ayrımcılık yapıldığını göstermektedir. Ancak halkın gözünde Arapça konuşanlar genellikle Suriyeli olarak bilinmekte ve tepkisel yaklaşıldığı söylenmektedir. Hatta bazen Vali'nin bile dil sürçmesi ile kentteki sığınmacıları "Suriyeli” olarak adlandırdığı söylenmiştir.

Sığınmacılara karşı ayrımcı tutum alışverişlerde, ev kiralamada yüksek fiyatlar isteme, çalışma ilişkilerinde düşük ücret ödeme gibi yasal mevzuattan da kaynaklanan farklı düzeylerde ayrımcılık ve hak ihlalleri olarak karşımıza çıkmaktadır. Örneğin Raşid (24) bir dükkandan indirimli tişört almak istediğini ancak kendisine indirim yapılmadığını bunun sebebini sorduğunda da "Siz Arapsınız, sizin paranız var zaten” karşılığını aldığını söylemiştir. 
İnsanların yüzde 20'si bize iyi davranıyor. Ama yüzde 80'ni kötü. Irak'ın durumunu bilmedikleri için böyle diyorlar. Irak'ın durumunu bilseler böyle demezler. Sadece karşılaştıklarımı anlatıyorum. Kimseyi kötülemek istemiyorum. Ama durum bu. Siz Türksünüz diye Türkleri övmek istemiyorum. Sadece yaşadıklarımı, gördüklerimi anlatıyorum. (Kamran, 27, Irakl1).

Araştırma bulguları Deniz ve arkadaşlarının (2016) ortaya koyduğu Suriyeli sığınmacıların karşılaştıkları sosyal dışlanma mekanizmalarına benzerlik göstermektedir. Düzce'deki sığınmacılar da mekânsal, ekonomik, kültürel, politik ve söylemsel olarak farklı dışlanma biçimleriyle karşılaşmaktadırlar. Sığınmacıların kötü barınma koşulları dışlanmanın mekânsal boyutunu bize göstermektedir. Gündelik pratiklerde çok çocukluluk, gürültü yapmak gibi sebeplerle ev sahipleri ve komşuları tarafından kültürel farklılıklar temelinde dışlanma ile karşılaşabilmektedirler. Sığınmacıların yaptıkları belirli işler ve güvencesiz çalışma biçimleri onların ekonomik dışlanmışlıklarının da bir göstergesidir. Politik ve söylemsel dışlanma biçimleri olarak "yurtlarını savunamayan", "yurtlarından kaçan" damgası ile hem Iraklılar hem de Suriyeliler değersizleştirilmekte ve ötekileştirilmektedir.

\section{Gelecek Planları: Düzce'de Beklemek ve Sabretmek}

Üçüncü bir ülkeye yerleştirme sürecinin uzaması, sığınmacıların kendi hayatları üzerindeki belirleyiciliğini büyük ölçüde yok etmekte ve aynı zamanda psikolojileri üzerinde olumsuz etkiler yaratmaktadır. Geçimini resim yaparak kazanan Iraklı sığınmacı Mushap (48) yaşadığı durumu şöyle aktarmıştır:

Kendim için hiçbir şey istemiyorum. Her şeye çocuklarım için katlanıyorum. Doktor olsun, mühendis olsunlar. Ama bunların hiçbirisi burada olmayacak. Burada bekleme süreci psikolojik olarak bizi çok etkiliyor. Ben resim bile çizmek istemiyorum. Bazen kalem elimde öylece duruyorum yarım saat. (Mushap, 48, Iraklı)

Görüşülen sığınmacıların üçüncü ülkeye gitmelerine referansla "sabretmek" ve "beklemek" kelimeleri en fazla kullanılan kelimelerden birisidir. Baki (32) içinde bulunduğu durumu şu şekilde dile getirmektedir:

Benim yerimde olmak istemezsiniz inanın bana. Her şeyim bir telefona bağli. Telefon her çaldığında koşuyorum. Her zaman telefonumu yanımda taşıyorum, tuvalete giderken bile. Telefonumu bırakamam. Sadece pazarları bırakabiliyorum. Çünkü BM o zaman çalışmıyor. (Baki, 32, Iraklı) 
Sadece çocuklarına iyi bir hayat kurmak istediğini söyleyen Lina (34) "Sadece kararı bekliyoruz. Tam beş yıldır Düzce'deyiz, bizim gibi arkadaşlarımızın çoğu Avrupa'ya gitti. Eğer BMMYK başvuruları kabul edilmezse ne yapacağını bilmediğini burada yardımsız yaşamayız” demiştir. Görüşmelerimiz, özellikle uzun yıllardır Düzce'de ikamet eden ve belirli bir yaşam kuran sığınmacıların çalışma gibi yasal haklara erişim ya da vatandaşlık istediklerini göstermektedir. Dört yıldır Düzce'de yaşayan ve ikinci mülakatını yapan Iraklı sığınmacı Baki (32) bu ortak isteği "Ben şikayet etmiyorum ama yasal bir statü istiyorum. Basit ve güvenli bir hayat istiyorum sadece" şeklinde dile getirmiştir.

\subsection{Mültecilik ve Toplumsal Cinsiyet}

Kadın sığınmacılar için savaşın travmasına ek olarak, toplumsal cinsiyete dayalı zulüm ve şiddetin sığınma kararlarında önemli bir rol oynadığını belirtmek gerekmektedir. Eşlerinden ve ailelerinden gördükleri toplumsal cinsiyete dayalı zulümden dolayı, kocaları öldürüldükten sonra dul birer kadın olarak ağır baskı ortamından kaçmak için ya da boşandığ 1 eşinin çocuğunu almak istemesinden dolayı kadınlar ülkesini terk ettiklerini söylemişlerdir.

Çocuk için Türkiye'ye geldim çünkü eşimle boşandım. Çünkü İran'da bir kural var, bir kadın boşandığı zaman babası çocuğu alabilir. ... İran'da o kurallar insanları bağlıyor, adalet yok, o baskı yüzünden Türkiye’ye geldim. (Maral, 31, İranlı).

Zeynep (30) ve Cemile (46) ise ailesi ve kocasıyla sorunlar yaşadığını, şiddete uğradıklarını ve Irak'a geri dönerse öldürüleceğini ifade etmişlerdir. Dilan (32) ise boşandıktan sonra asker olan kocasının öldürülmesi üzerine, tehdit edildiklerini ve Irak'ta dul bir kadın olarak baskı altında yaşamanın güçleştiğini anlatmıştır. Lina (34) ve Dilan (32) gibi çocuklu kadınlar özellikle Irak’ta devam eden çatışmalı ve istikrarsız ortamda çocuklarının geleceğinden endişe ettiklerini ve iyi bir hayat kurmak için Irak'ı terk ettiklerini söylemişlerdir. Toplumsal cinsiyete dayalı şiddetten ve rollerden kaçış, çocuk bakımı sorumluluğu, zorla evlendirme ya da kadın sünneti gibi toplumsal cinsiyetle ilişkili zulüm ve eziyet biçimlerinin kadınları göçe zorladığı bilinmektedir (Cawley, 1997; Freedman, 2015; Spijkerboer, 1994). Bazen de toplumsal cinsiyete dayalı zulüm genellikle diğer eziyet ve zulümlerin devamı olmakta ve özellikle savaş dönemlerinde kadınların tecavüz gibi araçlarla etnik temizliğin hedefi ya da doğrudan şiddetin hedefi olduğunu göstermektedir (Cockburn, 2004). Bizim araştırmamız da 
mevcut çalışmalara benzer şekilde kadınların sığınma sebeplerinin toplumsal cinsiyete dayalı zulüm ile doğrudan ilişkili olduğunu göstermektedir.

Sığınmacı kadınlar uydu kentte bekleme dönemlerinde de toplumsal cinsiyete dayalı şiddet biçimlerine maruz kalmaktadır. Görüşülen sığınmacı kadınlardan yarısı iş yerinde ya da özel yaşamlarında erkeklerin cinsel tacizine uğradıklarını söylemişlerdir. Genellikle işverenlerin ve kendi topluluklarından olan erkeklerin cinsel tacizine uğrayan sığınmacı kadınların özellikle ekonomik güçsüzlüklerinden ve tek başına yaşamalarından dolayı daha kolay taciz edilebilir görüldükleri anlaşılmaktadır. Nitekim bu tacizler genellikle iş bulma ya da maddi yardım karşılığında cinsel ilişkiye zorlanma şeklinde olmaktadır. Örneğin sik sık telefonla aranarak rahatsı edildiğini söyleyen Zeynep (30), "Burada yalnız olduğum için [erkekler] benimle olmak istiyorlar, buraya gelmek istiyorlar” demiştir. Cemile (46) de yalnız yaşadığı için insanların yardım ettiklerinde karşılık beklediklerini o yüzden artık kimseyle arkadaşlık yapmak istemediğini söylemiştir. Cemile bu ilişkilerden dolayı uğradığ tacizi anlatmıştır:

Çok sıkıntılar yaşadım. Daha önce hatta bir kere şikâyet ettim. O yüzden kalabalık istemiyorum. Iraklı bir adam vardı bana yardım ediyordu. Bize buzdolabı getirdi, yemek yoksa o getiriyordu. Çocuklara para veriyor hep yardım ediyordu. Ben ona şükrediyorum ama daha sonra ilerledi. Sana akşam geleceğim, ne zaman gelmek istiyorsam gelebilirim diyordu. Hayır, istemiyorum ben öyle bir kadın değilim dedim, sen zaten evli bir adamsın, sen beni yanlış anladın ben senin yardımı kabul ettim ama başka bir şeyi kabul edemem dedim $\mathrm{O}$ da beni tehdit etmeye başladı... Beni rahat bırakmayınca ben de tehdit etmeye başladım, seni şikâyet edeceğim dedim. ... Evet ettim. Emniyet'e [Göç İdaresine]. Adamı çağırdılar konuştular, araştırdılar sordular. Artık bu kadına yaklaşırsan kimliklerini alıız yurt dışına yollarız dediler. (Cemile, 46, Iraklı)

İGIM çalışanları tarafından tacizci erkeğin sadece uyarılması daha sonra dedikodunun büyümesi ve erkeğin ailesinin de kadını suçlaması ile durum kadının aleyhine dönmüş ve onu toplumsal olarak dışlandığı bir konuma sokmuştur. İnsanlar dedikodu yaptığ 1 için artık kimseyle görüşmek istemediğini söyleyen Cemile, korktuğunu ve gerek olmadıkça dışarı çıkmadığını söylemiştir.

Özellikle kocası ya da çocuğu olmayan kadınların ama genel olarak tüm sığınmacı kadınların muhafazakâr bir yapı gösteren Iraklı topluluk içinde katı toplumsal kurallarla karşılaştıkları anlaşılmaktadır. Görüşülenler erkeklerle arkadaşlık etmeleri, sevgili olmaları gibi dedikodulara maruz kaldıklarını söylemişlerdir. Hatta yeni evli olan Bibi (24) de kocası ile çarşıda el ele 
yürüdüğünde bile eleştirildiğini ve sürekli dedikodu yapıldığını söylemiştir. Sığınmacı kadınlardan Irak’taki gibi muhafazakâr davranış kalıplarını sürdürmelerinin beklendiği, uymadıklarında ise eleştiri ve dedikodu ile dışlandıkları anlaşılmaktadır. Kadınlara uygulanan bu toplumsal baskı yüzünden yaşamları daha da kısıtlanmaktadır. Boşanmış çocuklu bir kadın olan Dilan (32) ise bu tür dedikodulara uğramamak için sosyal ilişkilerinde tedbirli olduğunu ve fazla kişiyle görüşmediği için sorun yaşamadığını söylemiştir.

Karışmıyorum kimseye ya da tanıdık insanlar onlar, iyiler, iyi arkadaşlar, ben kötü insanlara karışmıyorum o yüzden büyük bir sıkıntım olmuyor. Arkadaşlarım belli bu, bu, bu ...öyle çok kalabalık bir arkadaşım yok. (Dilan, 32, Iraklı)

Bulundukları topluluk tarafından dışlanmaları sığınmacı kadınların mevcut psikolojik sorunlarının daha da derinleşmesine yol açmaktadır. Örneğin, ciddi bir sosyal dışlanma yaşayan Zeynep, "Sürekli düşünüyorum, sürekli sabrediyorum. Çok düşünmekten saçım beyaz oldu" sözleriyle içinde bulunduğu psikolojik durumu tarif ederken sürekli uykusuzluk çektiğinden şikâyet etmiştir. Benzer sosyal dışlanmalar, tek yaşayan sığınmacı kadınların kendi toplulukları içerisinde kurulan dayanışma ve yardımlaşma sayesinde daha rahat olacaklarına dair algıyı da düşündürmektedir. Keza, çoğu zaman aynı dili konuşan, aynı kültürü paylaşan, benzer topluluklar kadınların uğradığı şiddetin kaynağı da olabilmektedir. Nitekim tercümanların bütün hayat hikayelerini, tecavüz gibi toplumsal cinsiyete dayalı şiddet geçmişlerini ve özel yaşamlarını bildiği sığınmacı kadınların kendi toplulukları içinde bu katı ilişkiler yüzünden yeniden toplumsal cinsiyete dayalı şiddete uğradıkları görülmektedir. Bu yüzden sığınmacı kadınların kişisel bilgilerinin gizliliğinin korunması özel önem taşımaktadır.

Toplumsal cinsiyete dayalı şiddet ve tacize karşı ulusal anlamda psiko-sosyal ve ekonomik destekler Aile ve Sosyal Politikalar (ASPB) İl Müdürlüğü tarafından verilmektedir. Sosyal çalışmacıların istihdam edildiği ve psiko-sosyal destek anlamında tek kurum ise ASPB'dir. Ev içi şiddet ve kadına yönelik şiddetle ilgili Şiddet Önleme Merkezleri (ŞÖNIM), çocuklar için Sevgi Evleri ve yaşlılar için evde bakım ve yaşlı bakım evleri bu müdürlük altında faaliyet göstermektedir. Geçici kimlik numarasına sahip her sığınmacı ASPB hizmetlerinden yararlanabilmektedir. Ayrıca, Türkiye'nin imzaladığı Kadına Karşı Her Türlü Ayrımcılığın Yok Edilmesi Sözleşmesi (CEDAW) ve İstanbul Sözleşmesi (2011) gibi uluslararası sözleşmeler, yasal statüsünden bağımsız olarak göçmen ve sığınmacı kadınların 
da erkek şiddetine karşı kadınları koruma önlemlerinin alınmasını öngörmektedir. Ancak sığınmacıların bu hizmetlere erişimde de yetersiz tercümanlık, ulaşım ve bilgi yetersizliği gibi engeller bulunmaktadır. Nitekim KADİM Çalışanı A İranlı bir ailenin psikolojik destek için başvurduğunu ancak bir yere yönlendiremediklerini söylemiştir. Düzce'de tek yaşayan kadın ve çocuklu sığınmacı kadınların sayısının yüksek olduğunu ifade eden KADİM Çalışanı A, evlilik aracılığıyla ikamet izni alan kadınların oranının da yüksek olduğu vurgulanmıştır. İGİM Çalışanı C de özellikle evlilikle Düzce'ye gelen göçmen kadınların uğradığı ev içi şiddetle ilgili polise şikayet geldiğini şöyle ifade etmiştir:

Buraya gelip evlenmiş Türk vatandaşı olanlar da var, kocam beni dövüyor diye ama bunlar kapanmış şeyler, net olarak bir şey yok. ... Türk vatandaşıyla ayrıldıkları zaman sıkıntı oluyor. Ülkelerine geri dönüş olmak zorunda oluyor. (İGİM Çalışanı C)

Aynı görüşülen, kadına yönelik taciz ve ev içi şiddet ile ilgili şikayetlerde önce Emniyet'e sonra İGIM'e geldiklerini, kendilerinin de ASPB ile görüştüklerini ve Şiddet Önleme Merkezleri’ne (ŞÖNIM) iki ya da üç kadın ve bir çocuk yönlendirdiklerini söylemiştir. Ancak ASPB İl Müdürlüğü tarafından verilen bilgiye göre ŞÖNIM'lere dört göçmen ya da sığınmacı kadın müracaat etmiş ancak bu kadınlar İGİM'e yönlendirilmiştir. Görüşmelerimize ve gözlemlerimize dayanarak sığınmacı kadınların uğradığı toplumsal cinsiyete dayalı şiddet (TCDŞ) ve aile içi şiddet vakaları bürokrasi ve tercüman sıkıntısından dolayı ASPB İl Müdürlüklerine yansımamakta ya da bu müdürlüklerde çalışanlar destek mekanizmasını işletmekte isteksiz davranmaktadırlar.

Mevcut çalışmalar sosyal ağlardan yoksun olan, ekonomik zorluklarla mücadele eden, sağlık hizmetlerine ve eğitime kısıtlı erişimi, bilgi ve iletişim eksikliği olan mülteci kadınların bir de sosyo-ekonomik destekten mahrum olmasının kadına yönelik şiddet riskini daha fazla artırdığını ortaya koymaktadırlar (Keygnaert vd. 2012). Bu çalışma da kadın sığınmacıların farklı düzeylerde uğradıkları toplumsal cinsiyete dayalı şiddet biçimleri açısından, kadınlara yönelik sosyal hizmet ve destek mekanizmalarının önemine işaret etmektedir. Özetle, kadınların düzenli psiko-sosyal ve ekonomik desteğe erişememeleri onların önünde ciddi bir sorun ve erkek şiddetine karşı savunmasızlıklarını artıran bir etken olarak karşımıza çıkmaktadır. 


\section{Düzce'de Sosyo-Ekonomik Destekler ve KADİM}

Düzce İl Göç İdaresi Müdürlüğü’nün temel işlevi kente yeni gelen sığınmacıların kayıtlarını almak ve geçici kimliklerini çıkartmaktır. Daha sonra mülakat sürecini bekleyen sığınmacılardan Düzce uydu kentinde ikamet ederek, haftada bir ya da iki haftada bir imza atmak üzere İGIM'e gitmesi zorunludur. Yönlendirmeden ziyade kayıt odaklı bir faaliyet gösteren İGIMM aynı zamanda sığınmacıların doğrudan iletişim kurabildikleri ilk merkezdir. Dolayısıyla sığınmacıların da sürekli ziyaret ettikleri ve tercümanların varlığından dolayı sorunlarını dile getirebildikleri bir yer olmaktadır. Sığınmacıların kentte yaşadıkları en büyük sorunların barınma, sağlık ve geçim konularında olduğunu söyleyen İGIM Çalışanı C, "kaparo verip alamayanlar oluyor evden çıkartılanlar oluyor ama bunlar bize çok yansımıyor, biliyoruz yani gelip bize söylüyorlar ama resmi boyutu bizle alakalı olmadığı için o tarafa çok düşemiyoruz" demiştir. İl Göç İdaresi Müdürlüğü sosyo-ekonomik desteğe ihtiyaç duyan sığınmacıları Valilik çatısı altında kurulan Kardeşlik, Akrabalık, Dayanışma ve İletişi Merkezi kısa adıyla KADİM'e yönlendirmektedir.

Düzce'de Valilik bünyesinde 2017 yılında kurulan KADİM, sosyal destek mekanizmalarına erişim açısından yetkili ve diğer kurumlarla koordinasyonu sağlayan merkezi bir konumda bulunmaktadır. Bir web sitesi de bulunan KADİM (duzcekadim.org) Türkçe, İngilizce ve Arapça olarak barınma, istihdam, sağlık ve eğitim gibi haklar ve sosyo-ekonomik yardımlar hakkında bilgi vermektedir. KADİM Çalışanı A faaliyetlerini şöyle özetlemiştir:

STK'lar ve hayırseverlerle ortak çalışmalar yapmak, ayni yardım desteği, iş bulmaya destek, dezavantajlı gruplarla çalışmalar, gönüllü tercümanlık için öğrencilerle işbirliği, bilgilendirme broşürleri, kağıtsız bireylerin BMMYK başvuru sürecine katılmasına destek, halk eğitim kurslarıyla uyuma destek, kamu kurumlarına erişimde rehberlik ve aracılık etmektedir. (KADİM Çalışanı A)

Bu destekler KADİM'in ilişkide olduğu diğer kamu ve özel kuruluşlara yönlendirme yapılarak sağlanmaktadır. Örneğin İGIMM tarafından yönlendirilen sığınmacılara ihtiyaçları doğrultusunda ve STK'lar aracılığıyla ev eşyası, giyecek, gıda yardımı yapılmakta ya daiş ve kiralık ev bulmalarında destek olunabilmektedir. Üç personel ve bir tercümandan oluşan kadrosuyla KADİM, İGİM'den alınan bilgiler doğrultusunda mahalle ziyaretleri yaparak sığınmacı ve göçmenlerin kayıtlarını tutmakta ve bu bilgiler işbirliği yapılan diğer STKlar ile paylaşılabilmektedir. Düzce'deki sığınmacılara tek merkez- 
den sorunlarının çözümü ve diğer kurumlarla bir eş güdüm sağlamaya çalıştıklarını söyleyen KADİM Çalışanı A, "kısıtlı kaynakları adil dağıtabilmek için” STKlarla işbirliği yaptıklarını söylemiştir.

Görüşülen sığınmacılardan bazıları geçimlerini sağlayabilmek için kısıtlı sayıda da olsa Kızılay Kart'tan maddi destek, SYDV'den tek seferlik yardım ve bazı STK'lardan yardım aldıklarını söylemişlerdir. 2017 yaz aylarında görüşülen sığınmacılardan yalnız ya da çocuklu yaşayan üç kadın Kızılay Kart’tan faydalanmak üzere başvurmuş ve ilk yardımların yatırılmasını beklemekteydi. Ancak sığınmacı ailelerde çalışma yaşında erkeklerin olması durumunda bu yardıma erişimi güçleşmektedir. Bunun sebebi de çalışma yaşındaki erkeklerin çalışmasının beklenmesidir.

Ekonomik durumu kötü olan sığınmacılar bu alanda insani yardım yapan Düzce İHH, Beşir Derneği, Uluslararası Merhamet Cemiyeti Derneği, Biz Büyük Bir Aileyiz, MÜSİAD ve Erdemliler Derneği gibi sivil toplum örgütlerine yönlendirilmektedir. Örneğin insani yardım alanında aktif olan Düzce İHH eşya yardımı ve market alışveriş çeki desteği vermekte, sağlık sorunlarında yönlendirme, ilaç desteği ve hatta diş tedavisi yapabildiği söylenmiştir. İHH Hanım Komisyonu ise kadın sığınmacılara eğitim verdiği, Türkçe öğrenen öğrencilerin de derslerine destek olduğu söylenmiştir. Arapça bilen personel ve gönüllüler ile de çalışan Düzce İHH'nın 300 civarında sığınmacı ile irtibatta olduğu, Ramazan ve Kurban bayramlarında düzenli yardım yaptıkları ifade edilmiştir. STK'larla yardımların organizasyonu için nasıl çalıştıklarını KADİM Çalışanı A şöyle açıklamaktadır:

Yardım noktasında her derneğe on aile şeklinde dağıtıyoruz. Biz de yapacağız, onlar da yapacak. SYDV'nin gene maddi yardımı olacak ama yerel yardımların düzenli olması noktasında [STK'ları] itelim biraz istiyoruz, sürdürülebilir olsun istiyoruz, aç kalmasın aile istiyoruz. ... Amacımız, sistemi kuralım her STK'nın yardım ettiği aile profili olsun çünkü kapı kapı geziyor bunlar. Şöyle diyeyim giyim konusunda sıkıntı yok, yazın X firması SYD Vakfının temel destekçisi, giyim konusunda sürekli yardım yapıyorlar. Tabi giyiliyor sosyal market mağazalarımız var oradan alıyorlar. Yazlık ve kışlık çok talepler oluyor. İki ay sonra bir daha geliyor. Düzenli olarak veriyoruz. (KADİM Çalışanı A)

KADİM Düzce'de yardımların STK'lar aracılığıyla dağıtılmasını yönetme ve denetleme işlevini görmektedir; kısıtlı kaynaklarını ve yasal hak olarak tanımlanmayan bir takım sosyal destek mekanizmalarını STK'lar aracılığıyla 
gerçekleştirmeye çalışmaktadır. Ancak bu örgütlenen desteklere rağmen, görüşmelerimiz sığınmacıların temel haklara ve ihtiyaçlara erişimde zorluklar yaşadıkları göstermektedir. Bu zorlukların en önemli sebeplerinden birisi de Türkçe bilmemektir.

Sığınmacı ve mültecilerin hem hastaneler gibi kamu kurumlarına erişimde hem de yerel sosyal yaşama uyumda Türkçe öğrenimi ve iletişimi önemli bir araç olarak öne çıkmaktadır. Düzce İl Milli Eğitim Müdürlüğü ve Hayat Boyu Öğrenme Müdürlüğü tarafindan kentteki göçmen ve sığınmacılar için Türkçe okuma-yazma kursu, çeşitli mesleki eğitim kursları düzenlenmektedir. Ayrıca, Düzce Gençlik Merkezi Spor İl Müdürlüğü’ne bağl1 Gençlik Merkezi’nde genç sığınmacılara yönelik eğitim desteği ve boş zaman etkinlikleri düzenlenmektedir. KADİM de bazı mahallelerdeki ilkokullarda Halk Eğitim'in desteği ile Türkçe kurslarının açılmasını sağlamıştır. Ancak pek çok yetişkin sığınmacının çalışma, rahatsızlık ya da ev içi sorumluluklarından dolayı bu kurslara gidemediği anlaşılmaktadır. Örneğin görüşülen sığınmacı kadınlar ortalama olarak bir buçuk yıldır Türkiye'de bulunmalarına rağmen sadece içlerinden ikisi iyi derecede Türkçe konuşabilmekteydi. Beş yıldır Düzce'de yaşayan Lina (34), Türkçe öğrenmek istediğini ancak çocuklarını bırakacak yeri olmadığ 1 için kursa gidemediğini söylemiştir. Zeynep (30) ise iş bulduğu için Türkçe kursunu bırakmak zorunda kaldığını çünkü kursların gündüz olduğunu söylemiştir. Özellikle toplumsal cinsiyet rollerinden dolayı kamusal alana daha az katılan ve dışarıda çalışma imkânları kısıtlı olan kadın sığınmacıların erkeklere göre daha az dil becerisi geliştirdiği söylenebilir. Türkçe bilmemenin bir sonucu olarak görüşülenlerin komşularıyla ya da genel olarak Düzce'deki yerli halkla çok az düzeyde iletişim kurdukları gözlenmektedir.

\section{Sonuç ve Bazı Politika Önerileri}

Türkiye'deki YUKK ve Geçici Koruma Yönetmeliği ile oluşturulan yasal mevzuatlar, sosyal hizmete erişim anlamında savaşın travmasından ve zulümden kaçan sığınmacıların ihtiyaçlarını karşılamaktan uzaktır. Bu eksiklik yerel düzeyde sivil toplumun desteği ile aşılmaya çalışılmaktadır. Ancak bu destekler sosyal çalışmacılarının dahil olmadığı bir "hayırseverlik" anlayışından öte geçememektedir. Ayrıca bazı hakların tanımlanması sosyal hizmetlere erişimin sağlanması için yeterli bir koşul olmamakta, dil engeli, çalışma zo- 
runluluğu ve toplumsal cinsiyete dayalı sorumluluklar gibi engeller bu haklara erişimi kısıtlayabilmektedir.

$\mathrm{Bu}$ çalışma düzenli bir psiko-sosyal destek mekanizmasının bulunmadığ Düzce'de sığınmacıların çoğunlukla ekonomik, sosyal ve psikolojik sorunlarıyla baş başa kaldığını göstermektedir. Bir yandan ihtiyaçları için izinsiz çalışmak zorunda kalan diğer yandan sınır dışı edilme korkusu yaşayan sığınmacılar izinsiz çalıştıkları için işverenlerin hak ihlalleri ile çok sık karşılaşmaktadırlar. Barınma ve geçim sorunları sı̆̆ınmacılar için hayati bir öneme sahip olmakta, bu sorunlar savaşın travmasının yol açtığı psikolojik sorunlarını da derinleştirmektedir. Destek mekanizmalarına kısıtlı erişim sığınmacı kadınları ise iş veya maddi destek arayışlarında cinsel taciz gibi toplumsal cinsiyete dayalı farklı zorluklar ve risklere maruz bırakmaktadır. Bu yüzden özellikle sığınmacı kadınlara yönelik olarak barınma, ekonomik ve psikososyal desteklerin varlığı aynı zamanda toplumsal cinsiyete dayalı şiddetle mücadele için de elzemdir.

Düzce'deki sığınmacıların erişebileceği insan hakları merkezli bütünsel bir yaklaşım ile sosyal hizmetlere ihtiyaç duyulmaktadır. İçlerinde çocuk, genç, yaşlı, engelli ve tek yaşayan kadınların olduğu farklı sığınmacı grupların farklı sorunları ve ihtiyaçları bulunmaktadır. Bu ihtiyaçların analizi ve uygun çözümler üretilmesi gerekmektedir. Bu çözümler üretilirken ise insan odaklı, toplumsal cinsiyete duyarl1, sosyo-psikolojik destek ve yönlendirme mekanizmalarının kurulması gerekmektedir. 


\section{Kaynakça/References}

AFAD (Başbakanlık Afet ve Acil Durum Yönetimi Başkanlı̆̆ı) (2014). Türkiye'deki Suriyeli Kadınlar. Erişim tarihi, 12 Kasım 2017: https://www.afad.gov.tr/upload/ Node/2376/files/80-20140529154110-turkiye_deki-suriyeli-kadinlar_-2014.pdf

Biner, O. ve Soykan, C. (2016). "Bize Misafir dediler. Söyleyiniz, kimdir misafir? Var mıdır kanunda karşılı̆̆ı?”: Suriyeli Mültecilerin Perspektifinden Türkiye'de Yaşam. Erişim tarihi 21 Mart 2017: http://www.multeci.org.tr/belgeler.aspx

Buz, S. (2005). Türkiye'de Sığınmacıların Psiko-Sosyal Sağlığı, Toplum ve Sosyal Hizmet, 16(2), 93-105. Erişim tarihi 13 Mart 2016: http://www.tsh.hacettepe.edu.tr/

Buz, S. (2008). Türkiye Sığınma Sisteminin Sosyal Boyutu, TBB Dergisi, 21(77), 120130. Erişim tarihi 13 Mart 2016 : http://tbbdergisi.barobirlik.org.tr/

Coşkun, E. (2017). Sosyal Hizmetin Kapsamadıkları: Kağıısız Göçmen Kadınlar. Sosyal Hizmetlerde Güncel Tartışmalar: Sosyal Hizmetleri yeniden Düşünmek Konferanslarl içinde, Neşe Şahin-Taşğın, Uğur Tekin ve Yasemin Ahi (ed). (217-233) Ankara: Nika Yayınevi.

ÇSGB (2018). Çalışma İzin Harçları ve Değerli Kağıt Bedeli. Erişim tarihi 12 Ağustos 2018: https:/www.csgb.gov.tr/uigm/contents/calisma-iznine-dair-bilgiler/harcvebankabilgileri/

Cockburn, C. (2004). The Continuum of Violence: A Gender Perspective on War and Peace. Sites of Violence: Gender and Conflict Zones, içinde Wenona Giles ve Jennifer Hyndman (Ed.) Los Angeles: University of California Press. Doi: doi:10.1525/california/9780520230729.003.0002

Dedeoğlu, S. (2018). Tarımsal Üretimde Göçmen İşçiler: Yoksulluk Nöbetinden Yoksulların Rekabetine. Çalışma ve Toplum, 56, 37-68.

Deniz, A. Ç., Ekinci, Y. ve Hülür, A.B. (2016). Suriyeli Sığınmacıların Karşılaştı̆̆ı Sosyal Dışlanma Mekanizmaları. Sosyal Bilimler Araştırma Dergisi, 14(27), 17-40.

Demirbaş, H. ve Bekaroğlu, E. (2013). Evden Uzakta Olmak: Sığınmacıların/Mültecilerin Psikolojik Sorunları ve Alınacak Önlemler, Kriz Dergisi, 21(1-2-3), 11-24. Erişim 11 Ağustos $2018:$ http://dergiler.ankara.edu.tr

Ekiz Gökmen , Ç. (2011). Türk Turizminin Yabancı Gelinleri: Marmaris Yöresinde Turizm Sektöründe Çalışan Göçmen Kadınlar. Çalışma ve Toplum, 28, 201-232.

Erdoğan, M. (2015). Türkiye'deki Suriyeliler: Toplumsal Kabul ve Uyum. İstanbul: İstanbul Bilgi Üniversitesi.

Freedman, J. (2015). Gendering the international asylum and refugee debate. London: Palgrave Macmillan.

Güney, Ü. ve Konak, N. (2016). Bolu'da Suriyeli Ve Iraklı Sığınmacılar: Milliyetçilik, Erillik Ve Vatandaşlık Temelinde Öteki Algısı. Alternatif Politika, 8(3), 505-535. Erişim adresi 03 Mart 2017: http://alternatifpolitika.com

İçduygu, A. (ed). (2015). Syrian Refugees in Turkey: A Long Road Ahead. Migration Policy Institute. Erişim adresi: www.migrationpolicy.org 
İrfan, K. (2017).Suriyeli Mültecilerin Türkiye Işs gücü Piyasalarına Etkileri, İstanbul: Friedrich Ebert Stiftung. Erişim tarihi 11 Ağustos 2018: http://www.fes-tuerkei.org

Jessen, A. (2013). The Government of Turkey and Syrian refugees: A gender assessment of humanitarian assistance programming. Washington: Georgetown Institute forWomen, Peaceand Security. Erişim tarihi 15 Mayıs 2017: https://giwps.georgetown.edu

Kaya, A. ve Kıraç, A. (2016). İstanbul' daki Suriyeli Mültecilere İlişkin Zarar Görebilirlik Değerlendirme Raporu. Nisan 2016. Hayada Destek Derneği, İstanbul.

Keygnaert, I.,Vettenburg, N. ve Temmerman, M. (2012).Hiddenviolence is silentrape: sexual and gender-based violence in refugees, asylum seekers and undocumented migrants in Belgiumand the Netherlands, Culture, Health\&Sexuality, 14(5), 505-520. doi: 10.1080/13691058.2012.671961

Kivilcım, Z. (2016). Legal Violence Against Syrian Female Refugees in Turkey. Feminist Legal Studies, 24(2), 193-214. doi: 10.1007/s10691-016-9323-y

Kıvılcım, Z. ve Özgür- Baklacıoğlu N. (2015). Sürgünde Toplumsal Cinsiyet. İstanbul'da Suriyeli Kadın ve LGBTI Mülteciler. İstanbul: Derin Yayınları.

Lordoğlu, K. ve Aslan, M. (2015). Beş Sınır Kenti ve İşgücü Piyasalarında Değişim: 2011-2014, Göç Dergisi, 2(2), 249-267.

Nahya, N. Z. (2011) İmgeler ve Ötekileştirme: Cadılar, Yerliler, Avrupalılar, Atılım Sosyal Bilimler Dergisi, 1(1), 27-38.

Resmi Gazete (2016). Geçici Koruma Sağlanan Yabancıların Çalışma İzinlerine Dair Yönetmelik. Tarih: 15/1/2016 Sayı No: 29594. Erişim tarihi 13 Mayıs 2018: http://www. resmigazete.gov.tr/eskiler/2016/01/20160115-23.pdf

Sosyal Hizmetler Kanunu (2017, 24 Mayıs). Resmi Gazete, (Sayı: 18059). Erişim tarihi 13 Mayıs 2018: http://www.mevzuat.gov.tr/MevzuatMetin/1.5.2828.pdf

Spijkerboer, T. (1994). Women and Refugee Status; Beyond the Public/Private Distinction, Lahey: Emancipation Council.

Taşgın, N. Ş. ve Özel, H. (2011). Türkiye'de Sosyal Hizmetlerin Dönüşümü, Toplum ve Sosyal Hizmet, 22(2), 175-190. Erişim tarihi 23 Mayıs 2017 : http://www.tsh.hacettepe.edu.tr/

Tekin, U. ve Ertuş, G. (2017). Suriyeli Çocukların Türk Eğitim Kurumlarında Karşılaştıkları Sorunlar. Sosyal Hizmetlerde Güncel Tartışmalar: Sosyal Hizmetleri yeniden Düşünmek Konferanslarl içinde, Neşe Şahin-Taşğın, Uğur Tekin ve Yasemin Ahi (ed). (193-207) Ankara: Nika Yayınevi.

Toksöz, G., Erdoğdu, S. ve Kaşka, S. (2013). Irregular Labour Migration in Turkey and Situation of Migrant Workers in theLabour Market. Ankara: International Organisation for Migration. Erişim tarihi 26 Nisan 2017: http://www.iom.int

Tufan, B. vd. (2009, Ekim). Sosyal Bir Hak Olarak Sosyal Hizmet, Uluslararası Sosyal Haklar Sempozyumu Bildirileri Kitabı.Antalya. (76-86). Erişim tarihi 14 Mayıs 2017: http://www.sosyalhaklar.net/2009/bildiri/2009sosyalhakalr.pdf 
Tunç, A. Ş. (2015). Mülteci Davranışı ve Toplumsal Etkileri: Türkiye'deki Suriyelilere İliş̧kin Bir Değerlendirme. Tesam Akademi Dergisi, 2(2). 29-63. Erişim tarihi 26 May1s 2017: http://tesamakademi.com/tr/

UGÖ (Uluslararası Göç Örgütü - IOM) (2017). IOM TurkeyHelpsResettleOver 21,000 Refugees in 2016. Erişim tarihi 14 Mayıs 2017: https://www.iom.int/news/iom-turkeyhelps-resettle-over-21000-refugees-2016

UNHCR (2018). UNHCR tarafindan kayıt ve MSB. Erişim tarihi: 24 Eylül 2018. http:// help.unhcr.org/turkey/tr/information-for-non-syrians/reception-registration-and-rsdwith-unher/

UNHCR (United Nations High Commissioner for Refugees) (2017) 2017 UNHCR Monthly statistics. Erişim tarihi 17 Eylül 2017: http://www.unhcr.org/tr/wp-content/ uploads/sites/14/2017/02/eng(67).pdf

UNHCR (United Nations High Commissioner for Refugees) (2016a) Syria regional refugee response. Erişim tarihi: 17 Eylül 2017. http://data.unhcr.org/syrianrefugees/country.php?id=224

UNHCR (United Nations High Commissioner for Refugees). (2016b). Convention and Protocol Relating to the Status of Refugees. Erişim tarihi: 17 Eylül 2017. http://www. unhcr.org/3b66c2aa10

YUKK (Yabancilar ve Uluslararas1 Koruma Kanunu). (2013, 11 Nisan). Resmi Gazete. (Sayı: 28615). Erişim tarihi 14 Mayıs 2017: http://www.mevzuat.gov.tr/MevzuatMetin/1.5.6458.pdf

Zengin, O. ve Altındağ, Ö. (2016). Bir İnsan Hakları Mesleği Olarak Sosyal Hizmet, Toplum ve Sosyal Hizmet, 27(1), 179-190. Erişim tarihi 17 Eylül 2017: http://www. tsh.hacettepe.edu.tr/ 